IZA DP No. 9392

Heterogeneity of Skill Needs and Job Complexity: Evidence from the OECD PIAAC Survey

Konstantinos Pouliakas

Giovanni Russo

September 2015 


\title{
Heterogeneity of Skill Needs and Job Complexity: Evidence from the OECD PIAAC Survey
}

\author{
Konstantinos Pouliakas \\ CEDEFOP, \\ University of Aberdeen and IZA
}

\author{
Giovanni Russo \\ CEDEFOP \\ and IZA
}

Discussion Paper No. 9392

September 2015

\author{
IZA \\ P.O. Box 7240 \\ 53072 Bonn \\ Germany \\ Phone: +49-228-3894-0 \\ Fax: +49-228-3894-180 \\ E-mail: iza@iza.org
}

\begin{abstract}
Any opinions expressed here are those of the author(s) and not those of IZA. Research published in this series may include views on policy, but the institute itself takes no institutional policy positions. The IZA research network is committed to the IZA Guiding Principles of Research Integrity.

The Institute for the Study of Labor (IZA) in Bonn is a local and virtual international research center and a place of communication between science, politics and business. IZA is an independent nonprofit organization supported by Deutsche Post Foundation. The center is associated with the University of Bonn and offers a stimulating research environment through its international network, workshops and conferences, data service, project support, research visits and doctoral program. IZA engages in (i) original and internationally competitive research in all fields of labor economics, (ii) development of policy concepts, and (iii) dissemination of research results and concepts to the interested public.
\end{abstract}

IZA Discussion Papers often represent preliminary work and are circulated to encourage discussion. Citation of such a paper should account for its provisional character. A revised version may be available directly from the author. 
IZA Discussion Paper No. 9392

September 2015

\title{
ABSTRACT \\ Heterogeneity of Skill Needs and Job Complexity: Evidence from the OECD PIAAC Survey*
}

\begin{abstract}
We use information from the new OECD Survey of Adult Skills (PIAAC) to investigate the link between job tasks and cognitive skill demand in 22 advanced economies. Skill demand is operationalized by the assessed literacy and numeracy skills of workers with well-matched skills to their job duties. Jobs are categorised according to the nature of tasks, including the intensity of abstract reasoning, employee latitude, interactivity or manual work. The analysis confirms the significant relation between task complexity and higher skill needs. The significant relation holds independently of the endogenous supply of formal human capital, occupational or industrial structure and other job or individual characteristics. The results confirm the (indirect) mapping between tasks and skills as predicted by the task approach to labour economics. Given the marked heterogeneity in workplace practices adopted by employers, it is clear that enterprise level workplace development policies are warranted as enablers of skills matching and higher labour productivity.
\end{abstract}

JEL Classification: J24, M12, M54

Keywords: $\quad$ skills, tasks, skill demand, job complexity, PIAAC, mismatch

Corresponding author:

Giovanni Russo

European Centre for the Development of Vocational Training (CEDEFOP)

Europe 123

Thessaloniki (Pylaia), 55102

Greece

E-mail: giovanni.russo@cedefop.europa.eu

\footnotetext{
* The paper has benefitted from comments by Pascaline Descy (Head of Department, Skills and Labour Market, Cedefop), participants at the conference on 'New Research in the Economics of Educational and Skill Mismatch' held at the University of Aberdeen (UK) in August 2014 and at a seminar at the International Hellenic University (Salonica, Greece) in February 2015. The views expressed in the paper are solely the authors' and do not necessarily represent those of the European Centre for the Development of Vocational Training (Cedefop). The usual disclaimer applies.
} 


\section{Introduction}

The 'task approach' to analysing skill requirements in advanced market economies has received increasing attention in recent literature (Autor et al. 2003; Autor and Handel 2013). The crux of the task framework is that the core activities that workers undertake in their jobs are linked to the (formal, non-formal and informal) skills required by workers to carry out these tasks. The degree to which labour with different skill levels is needed is determined endogenously according to technological changes, the relative availability of factor supplies and the comparative advantage of different skill types in the execution of distinct tasks (Acemoglu and Autor 2011). Job task requirements are linked to evolving technologies, including the reduced cost of ICT, and to automation of a large set of routine tasks that, as a consequence, has shifted relative labour demand away from occupations in need of individuals with intermediate-level skills. For instance, Handel (2012) shows, in both the US and Europe, that the trend towards a post-industrial society during the period 1997-2009 involved rising demand for both cognitive and interpersonal skills and declining demand for physical tasks.

The task framework offers an unique theoretical construct that can account for several stylised empirical facts in the labour markets of advanced economies over the last three decades, including the hollowing out ("polarisation”) of the occupational distribution of employment (Acemoglu and Autor 2011). ${ }^{2}$ Autor and Handel (2013) illustrate further that the variance in analytical, routine and manual tasks carried out by US workers is a significant predictor of wage differences not only between occupations but also among workers in the same occupation.

Much of the previous literature on the effectiveness of high performance workplaces $(\mathrm{HPW})^{3}$ has also confirmed that there is a positive relation between discretionary employee workplace practices and various metrics of productivity, including job satisfaction (Bauer 2004), health and safety at work (Pouliakas and Theodossiou 2013) and firm performance (Bloom and Van Reenen 2011). Nevertheless, even though it is usually assumed that the positive effect of task discretion and autonomy on productivity is mediated by higher levels of human capital, little evidence exists to date to confirm the statistical relationship between

\footnotetext{
${ }^{2}$ Nonetheless, other authors have pointed out that polarization is not taking place everywhere at the same pace, with some EU countries experiencing different types of changes in their job structure (Fernández-Macías 2012; Eurofound 2014).

${ }^{3}$ The literature on HPW suggests that human resources are at their most productive capacity when they are confronted with complex, autonomous, non-routine tasks (UKCES 2009). Firms relying on HPW often implement specific job design, hiring, training, communication and performance management measures to ensure that they attract a highly skilled workforce that continuously develops and utilises its skills on the job.
} 
the complexity of task design and the heterogeneity of (cognitive) skills and skill requirements between and within occupations. As noted by Autor and Handel (2013, p. S61), “...the task approach faces two significant challenges. The first is conceptual. Research using the task approach has not to date made explicit the economic mapping between tasks, which are characteristics of jobs, and human capital, which is a characteristic of workers...The second challenge is measurement". Indeed, most previous studies have been constrained in the use of imperfect proxies of skills, such as formal educational qualifications. They have also been limited in their ability to adequately distinguish between different levels of skills, often relying on discrete groupings of educational attainment (e.g. low, medium and high).

This paper addresses this critical disjuncture between skills and job tasks by taking advantage of a new rich data source generated by the Organisation for Economic Cooperation and Development (OECD), the so-called Survey of Adult Skills or PIAAC (OECD 2013). The PIAAC survey is unique as it assesses objectively the level of foundation skills of individuals, specifically their literacy, numeracy and problem-solving (in technology-rich environments) cognitive functions. It also contains a separate module with information on the frequency of performing different job tasks, which enables the construction of person-level (instead of the conventional occupation-level) measures of heterogeneity in task demands. ${ }^{4}$

The paper examines whether the demand for skills in a sample of 22 economies is correlated with different descriptors of task complexity characterising people’s jobs, such as the extent to which their jobs entail abstract, autonomous, interactive or manual tasks. To do so, newly proposed measures capturing variation in skill requirements between and within occupations, as proposed in recent literature, are derived. Specifically, the heterogeneity of skill needs is captured by focussing only on jobs in which individuals' skills are wellmatched to their job duties, the latter measured both in a subjective and an objective fashion.

It is confirmed that skill demand is positively and statistically significantly related to the complexity of job tasks. Other things equal, jobs that engage employees more frequently in the execution of complex and abstract tasks are more likely to be characterised by higher (cognitive) skill needs. This positive relation holds even after taking into account other explanatory factors that can account for the variation in skill requirements across firms, such

\footnotetext{
${ }^{4}$ With the exception of Autor and Handel (2013), researchers have typically imputed task requirements using data on job characteristics at the level of occupations, as obtained from national occupational dictionaries or libraries (e.g. the information tool O*NET in the US).
} 
as the occupational and industrial distribution, establishment size, distinct recruitment requirements and other workplace and individual characteristics.

The paper thus offers an empirical validation of the indirect link between tasks and skill needs as predicted by the task approach of labour economics. Such a relation is important for policymaking purposes, as it implies that enterprise level HR interventions and workplace innovation publicly-financed projects (aimed at improving job design and work practices or introducing new forms of work organisation) can potentially influence the level of skill demand in local or national economies. ${ }^{5}$ Raising the level of skill demand and of "employer ambition" (European Commission 2008) in terms of how skills can be better developed and deployed within enterprises, has been acknowledged as a key challenge in the ambit of skills policy (Buchanan et al. 2010). Stimulating higher levels of skill demand and making better use of workers' skills holds the key to raising labour productivity and mitigating skill mismatches (particularly, high levels of overqualification/skill underutilisation) in advanced western economies (OECD 2013; Cedefop 2012a; Cedefop 2015a).

The structure of the paper is as follows. Section 2 reviews the available literature regarding the relation between task complexity and skill needs. Section 3 describes the main variables used in the analysis based on the PIAAC dataset. Section 4 outlines the empirical methodology adopted in the paper and discusses the main findings while section 5 describes several tests which confirm their robustness. Section 6 concludes with a discussion of the policy relevance of the empirical results of the paper.

\section{Job design and skill needs}

\subsection{Jobs as tasks}

Job design and the degree of task complexity involved in jobs is a strategic decision for organisations. One of the most challenging questions for human resource managers is the definition of a job description: that is, specifying the tasks assigned to a given job title, the authority and discretion granted to employees performing such jobs and the incentives tied to such jobs, which aim at influencing the behaviour and motivation of employees. Unsuccessful organisational structures that result in hierarchical 'silos' and isolated or routine

\footnotetext{
${ }^{5}$ For instance, a number of recent government initiatives to help small and medium-sized enterprises boost their productivity and performance by embracing and embedding innovative workplace practices, while developing employee participation and empowerment as enablers of change and creativity have been implemented in several countries, such as the Finnish Workplace Development Programme, the Synergy programme in Flanders (Belgium), the Workplace Innovation Fund in Ireland and the Workplace Productivity Project in New Zealand (Buchanan et al., 2010).
} 
jobs can demotivate employees, inhibit effective communication channels within the firm and result in a strained and unproductive working environment (CIPD 2008).

As described by Lazear and Gibbs (2009), most jobs can be described by four interlinked components - the number of tasks to be performed (i.e. multitasking), the breadth and depth of ability and human capital needed by the job (i.e. skills), the degree of control, responsibilities borne and number of decisions made by workers (i.e. discretion) and the linkage with other jobs in the firm (i.e. interdependence). These factors are interlinked when designing jobs, namely jobs with a higher level of multitasking will also entail a greater degree of task discretion and will be dependent on the higher skills of job holders (Gibbs et al. 2010).

The Tayloristic principle espouses fragmentation of jobs into separate and identifiable tasks involves clear-cut roles and responsibilities among workers, sliced up into simple repetitive tasks and facilitated by piece rate pay and vertical bureaucratic hierarchies, which allow for efficient monitoring of worker effort. Although this approach facilitates organisational performance, particularly in assembly line environments, it implies a low demand for skills and a high level of job dissatisfaction. However, Herzberg's two-factor theory of motivation and job enrichment and the research it spurred in the 1970s, including the Job Characteristics model (Hackman and Oldham 1976), emphasises the importance of allowing workers to have control over aspects of their job (e.g. timing, methods) for boosting their motivation and organisational effectiveness.

Along with the so-called skill-biased technological change that took place in most advanced economies in the 1980s (Katz and Autor 1999), a new organisational paradigm is also said to have prevailed that underpinned a rising demand for skills (Caroli and Van Reenen 2001). The skill-biased organisational change (SBOC) hypothesis asserts that due to rapid changes in global markets and advanced technologies a greater share of firms decided to enrich their jobs by allowing for a greater multitasking and employee autonomy, as a means of facilitating discretionary effort and motivation among staff. ${ }^{6}$ This transformation in work organisation has subsequently implied greater skill needs on behalf of companies. Together, changing work organisation practices and the availability of higher educated workforces are believed to have facilitated the interlinked outcomes of higher employee engagement, productivity and superior business performance.

\footnotetext{
${ }^{6}$ Some refer to this change as 'smart working', 'an approach to organising work that aims to drive greater efficiency and effectiveness in achieving job outcomes through a combination of flexibility, autonomy and collaboration, in parallel with optimising tools and working environments for employees' (CIPD, 2008, p. 4).
} 
Prominent theories of job design stress the interaction with human capital and incentives when firms decide how to shape and structure tasks in jobs (Lazear 1992; Prendergast 1995). As illustrated by Acemoglu and Autor's (2011) assignment framework, the equilibrium assignment of skills to tasks will be determined in accordance with the comparative advantage of different skill groups across task categories and the rewards for those tasks. Individuals may self-select into challenging jobs with more task discretion depending on their own attitudes to learning and other intrinsic preferences and dispositions. Moreover, skill demand interacts with the relative supply of skills, both internally and in the external labour market. As more workplaces transit towards flatter and horizontal hierarchical structures, rendering workers increasingly empowered and independent, higher skilled employees are, in turn, more likely to have opportunities to design their own ways of working and maybe even shaping their own job descriptions (Syedain 2007; CIPD 2008, p. 19).

Job design emphasising greater task discretion and employee control has been considered to be a key ingredient of the shift to high performance work (HPW) systems (Huczynski and Buchanan 2001). HPW systems are concerned with a wider bundle of human resource and organisational management practices, including the institution of enhanced channels of communication to facilitate employee engagement (e.g. autonomous teams, job rotation, quality circles), improved recruitment and training strategies for skill enhancement (e.g. careful screening, formal assessment tools and competence management) and the adoption of performance targets and reward instruments to incentivise employee motivation (e.g. incentive pay) (Applebaum et al. 2000). Empirical studies tend to show a positive relation between HPW practices and measures of organisational performance (Huselid 1995; Bauer 2004; DTI and CIPD 2006). There is also broad consensus that the positive impact of HPW on firm performance holds only when different 'bundles' or clusters of HR practices are used, instead of in isolation (Macduffie 1995; Ichniowski et al. 1997). However, the causality and the factors that mediate the relationship (e.g. employee commitment; improved information flows; skills) is under dispute and is often considered to be a 'black box' (Ichniowski and Shaw 2003; Bloom and Van Reenen 2011; Cedefop 2012a).

\subsection{Business and management strategies, job tasks and skills}

Organisations are heterogeneous entities in nature. Even within particular industries some organisations are top performers in terms of the management practices used and others are laggards. The World Management surveys have revealed important differences in management practices between countries, but, most importantly, they have also highlighted 
that marked discrepancies exist within countries and sectors (Bloom and Van Reenen 2007; Bloom and Van Reenen 2010; Eurofound 2011). These diverse management practices, of which talent management is a key pillar, can partially account for the residual productivity gap between firms, namely the difference in productivity even after taking into account dissimilar stocks of factor inputs.

This diversity of management practices between firms is often the outcome of strategic business choices made with the aim of securing competitive advantage, as influenced by technological forces, factor input endowments, target markets (e.g. local, regional, international) and other relevant factors (e.g. location, marketing strategy, organisational culture inter alia). The overall choice and effectiveness of diverse HRM practices is dependent on business strategy. ${ }^{7}$ Firms that adopt business strategies based on product market diversification, quality and innovation tend to be accompanied by the design of more complex jobs and a higher demand for skills and, subsequently, greater chances of skill shortages (Stahl 2013; Cedefop 2015b). The business and product market strategy selected by firms will thus be mirrored in differential job design, with marked implications for the allocation and utilisation of the skills of staff.

Wright et al. (1994) have also suggested that the ability of organisations to systematically implement HPW practices is intrinsically dependent on the underlying technology of production. When production processes are more complex, when it is less costly to convert ongoing operations (e.g. as would be the case for younger aged plants) and when the quality rather than the quantity of output is critical, HPW practices are more likely to be adopted (Lazear and Oyer 2009). The ability of some firms to monitor the effort of employees and to sanction poor performance will also determine whether they design jobs that offer more or less discretion to their workforce.

Task heterogeneity is also intimately linked to the quality of employer-employee relations. Complex jobs bestow some degree of autonomy to incumbent workers to allow for greater flexibility to respond to unpredictable occurrences. As a consequence, they must be dependent on high trust relationships between management and the workforce. Employers cannot observe or control what employees do to the same extent as in a command and control environment. A psychological or relational contract is therefore required between employers and workers, which allows employers to have confidence that workers will exercise their autonomy to the best interest of the organisation and employers will reciprocate by some

\footnotetext{
${ }^{7}$ An employer survey in the UK, for example, indicated that $69 \%$ of establishments agreed with the proposition that their HR strategy is closely linked to their business strategy (UKCES 2008).
} 
form of gift-exchange. More complex and autonomous jobs may therefore require profound changes in organisational culture that take time and commitment to be realised.

For the aforementioned reasons, several authors have cautioned that the application of smart working or HPW principles is contextual and that such work practices cannot be universally and uniformly applied to all firms in the economy, leading to potential selectivity bias (Ichniowski and Shaw 2003). Furthermore, several other key issues need to be taken into account when assessing the effectiveness of HR practices. The drivers (i.e. why would a firm adopt them in the first place?), intended outcomes (is the goal to increase productivity, profitability, sales, employee job satisfaction etc.?) and the means of implementation (what is the best way of incorporating them in the existing business strategy?) are key parameters for determining the context under which HR strategies are beneficial for enterprises.

From the above it is evident that, a priori, the heterogeneity of tasks among different jobs in the labour market is expected to exert an independent yet contextual influence on levels of skill demand, with many confounding mechanisms underpinning the relationship. While the dataset employed for the empirical analysis in this paper does not contain information on several important contextual variables related to organisational strategy, it does permit consideration of a number of controls that had not been available in previous empirical studies. With the above caveats in mind, the remainder of this paper sets out to investigate the empirical relationship between task heterogeneity and skill requirements using data on 22 countries from the recent OECD PIAAC survey.

\section{Data and descriptive statistics}

\subsection{The Programme for the International Assessment of Adult Competencies (PIAAC)}

The Survey of Adult Skills is a product of the OECD's Programme for the International Assessment of Adult Competencies (PIAAC) (OECD 2013). The survey is designed to provide valid and reliable estimates of adults' competences in key information-processing skills, including literacy, numeracy and problem solving in technology-rich environments. ${ }^{8}$ To achieve this, the respondents undertook assessment tests specifically designed by experts to decouple the capacity of adults to respond to the contemporary challenges of knowledge economies. The survey also enables the identification of differences in skills proficiency between sub-groups of the population and the impact on their life chances, as it collects

\footnotetext{
${ }^{8}$ Skill scales in all three domains have been constructed using adaptive testing, while plausible values are calculated using Item Response Theory (IRT).
} 
extensive background information on individuals' formal and non-formal learning activities, educational attainment, employment status, demographic and socioeconomic characteristics. A key contribution of PIAAC is that it also contains modules enquiring about the frequency of use of several tasks (e.g. reading, writing, numeracy, ICT, cooperating with co-workers, instructing people, giving presentations, selling products, planning activities, solving complex problems, working physically) in people’s jobs and in their everyday lives.

\subsection{Sample used in empirical analysis}

The international public use data files were obtained for 22 countries that participated in the PIAAC exercise. ${ }^{9}$ These were subsequently merged to comprise a file of 152,514 individual cases. ${ }^{10}$ For the purposes of the analysis, the original sample was restricted to include only individuals in paid employment at the time of the survey. The self-employed and those employed in the armed forces were subsequently dropped so that the sample is only comprised of paid civilian employees. To avoid confounding the analysis with individuals whose main activity status is not predominantly paid employment, the sample was further restricted by relying on the self-reported activity status of individuals during the previous year. Cases that regarded themselves to be primarily students, apprentices, disabled, in retirement or in the army were deleted, as were very young individuals aged 16-19.11 Finally, individuals with usual weekly working hours below eight (i.e. those who did not complete at least one day of equivalent full time work in a week) were also dropped. The final sample is therefore comprised of 80,602 cases.

The empirical analysis relies only on two of the three domains of skills assessed in PIAAC, namely literacy and numeracy. ${ }^{12}$ The reason is that the assessment of problemsolving skills in technology-rich environments was only administered to a subgroup of the population, namely individuals who reported that they had at least some computer experience to enable them to take the computer-based assessment. Including this domain in the analysis

\footnotetext{
9 Austria, Belgium (Flanders), Canada, Cyprus, the Czech Republic, Denmark, Estonia, Finland, France, Germany, Ireland, Italy, Japan, South Korea, the Netherlands, Norway, Poland, the Slovak Republic, Spain, Sweden, the United Kingdom (England and Northern Ireland) and the United States. Around 166,000 adults, aged 16-65, were interviewed in each country using a combination of computer-assisted and pen-and-pencil personal interviews. The achieved samples ranged from a minimum of approximately 4500 to a maximum of nearly 27300 in each country/sub-national region.

$10 \mathrm{http}: / /$ www.oecd.org/site/piaac/publicdataandanalysis.htm

${ }^{11}$ Students and apprentices were excluded as they are often at the cross-roads between work and the educational process, often employed in part-time, informal or low-paid jobs for a limited duration of time.

12 We use Cronbach's alpha statistic to obtain an aggregate measure of each individual's skill literacy and numeracy level on the basis of his/her ten plausible values obtained from the IRT procedure.
} 
would therefore significantly reduce the sample size and introduce non-random selection bias. As a consequence, the measures of skills used in the paper only capture the basic numeracy and literacy skills of individuals. It is anticipated that if a positive association between task complexity and cognitive skills is found, it is reasonable to expect that this positive effect may also extend (or even be stronger) for other generic skills. This hypothesis is based on literature on HPW, which has typically shown that many of these work practices involve the deployment of a wide range of workers' cognitive and non-cognitive skills in the workplace (e.g. problem solving, communication skills) (Whitfield 2000, p. 3).

\subsection{Measures of task complexity}

To derive measures of task complexity, a conventional procedure adopted in recent analyses in literature was followed (Spitz-Oener 2006; Autor and Handel 2013). Specifically, job tasks were modelled and aggregated along four broad dimensions: (i) abstract reasoning, (ii) job latitude, (iii) interaction/influencing tasks and (iv) physical/manual work. The information used to derive the dimensions of task complexity was compiled from the relevant modules of the PIAAC survey, which measure the frequency of use of skills at work, or directly from the background questionnaire. The PIAAC scales are defined on a 1-5 scale, such that a higher score on the scale corresponds to a higher incidence/importance of the task in terms of frequency or percentage of time dedicated to the task (e.g. 1 = never; $5=$ everyday).

Abstract reasoning refers to the ability of individuals to analyse information and solve problems on a complex, thought-based level. To engage in abstract reasoning, individuals require skills such as the ability to form theories about objects, ideas and processes; understand subjects on a complex level through analysis and evaluation; apply knowledge in problem-solving using theory and complex analogy and understand relationships between ideas and concepts.

As in Karasek's (1979) demand-control model of job stress, job or decision latitude refers to employees' control over their tasks and how those tasks are executed. In particular, it captures the degree to which the job involves a variety of tasks and/or low levels of task repetition, including the ability of employees to influence and make decisions about their own job.

Furthermore, a separate construct capturing the extent of cooperation and influencing other people inside or outside of the organization (e.g. clients, co-workers, other external 
audiences) has been derived. Finally, a direct measure of the frequency of physical work for a long period in one’s job has also been adopted.

To derive the respective indices of task complexity, activities associated with similar tasks, as contained in the PIAAC questionnaire, were grouped together, under the condition that Cronbach's alpha reliability coefficient exceeded a value of 0.7. Table 1 summarises the process of construction of the main task complexity scales. ${ }^{13}$

\section{[INSERT TABLE 1 ABOUT HERE]}

\subsection{Indirect measures of skill demand}

Obtaining reliable measures of skill demand is a challenging endeavour. Previous literature has attempted to proxy for the skill requirements of jobs using somewhat indirect methods. These have typically relied on employment trends in broadly defined occupational or educational groups (Cedefop 2012b) or on the average level of educational attainment in occupations (Sloane et al. 1999; Groot and Maasen van der Brink 2000; Pouliakas 2012). Other measures have included the mean years of work experience required to perform job tasks adequately or self-reported measures of the frequency or importance of skills for doing one's job (Cedefop 2015a). However, most of these are indirect proxies of skill demand and suffer from subjectivity bias and an inability to adequately distinguish skill needs from endogenous labour supply/effort choice.

This paper utilises two relatively distinct measures of skill demand, exploiting newly proposed measures by Pellizzari and Fichen (2013) and Allen et al. (2013). The first measure focuses on the skill level corresponding to workers who are well-matched to their job duties. The second attempts to establish a range of 'usual skills use' for persons with a comparable skill level and is, thus, a measure of the standard intensity of skill use within jobs. Both can be considered to constitute proxies of the depth and breadth of skills required so that workers' skills are well-matched/well-utilised in their jobs. The decision to use both approaches in the paper as the main dependent variable has been taken given that each measure encapsulates a qualitatively different aspect of skill demand (Ashton and Sung 2011). Important, yet contentious, methodological challenges have also been identified for either of these two measures in literature.

\footnotetext{
${ }^{13}$ The scales are robust to different methods of deriving the task constructs. For example, similar empirical results are obtained when the job complexity scales are derived using principal component analysis and each scale is derived using the items' loadings on the first principal component (i.e. one with an eigenvalue above 1).
} 
To construct what is known as the OECD measure of skill mismatch, Pellizzari and Fichen (2013) rely on direct indicators of workers' skill proficiency as obtained from the purposely designed assessment exercise. They obtain their measure of skill requirements by relying on the subjective answers of respondents to dedicated questions in the survey regarding the match of their skills with those needed by their jobs. In particular, they assume that minimum and maximum thresholds of the skill level demanded in jobs (for a given skill domain) can be inferred by the assessed proficiency levels of workers who have self-reported well-matched skills i.e. workers who believe their skills correspond well to those required to perform their job duties. ${ }^{14}$ The authors subsequently classify individuals as (objectively) well-matched in a proficiency domain if their own proficiency score falls within the "typical skills range" required by their occupation in their country, the range defined by the minimum and maximum scores as described above (see Figure 1). ${ }^{15}$

\section{[INSERT FIGURE 1 ABOUT HERE]}

By contrast, Allen et al. (2013) argue that the OECD measure of skill requirements has some methodological flaws as it only takes into account the heterogeneity of skill demand within broad (1-digit) occupational categories. Selectivity bias is also likely to affect the results, given that the 'typical skills range' based on the subjectively matched group is obtained from a very small part of the whole sample of employees (9\%). The skill requirements of this group also tend to be, on average, the lowest compared to other population groups (i.e. the self-reported overskilled and underskilled), raising concerns about the overall representativeness and unobserved characteristics of this subpopulation. For these reasons, the authors focus on the rich battery of questions on the self-reported frequency of skills use at work, although this is not without contention too.

The OECD (2013) has argued that frequency of skill use is a different notion relative to the level of skill required to do a job. Nevertheless, Allen et al. (2013) have defended the validity of their measure by presenting significant empirical evidence that skill use is quite strongly correlated with skill level. However, they insist that their construct primarily constitutes a measure of the intensity of use of skills relative to what is usual for workers of a

\footnotetext{
${ }^{14}$ This sub-set of well-matched workers is identified by a negative answer to the following two questions: "do you feel that you have the skills to cope with more demanding duties than those you are required to perform in your current job?" and "do you feel that you need further training in order to cope well with your present duties?".

${ }^{15}$ For the purposes of this paper we have adopted the more stringent thresholds of Pellizzari and Fichen (2013), whereby the lower and upper thresholds of the skills distribution have been cut-off at the $5^{\text {th }}$ and $95^{\text {th }}$ percentiles, respectively.
} 
given skill level. What constitutes 'usual skills use' for a given skill domain is given by cases where the difference between the (standardised) skill proficiency level and degree of skill use of individuals falls within the range of $[-1.5,1.5]$ standard deviations around the mean. It is thus reasonable to assume that individuals in this group utilise their skills efficiently as part of their job tasks. This is true regardless of whether their own skill level corresponds to the level most commonly required by their job.

Utilising both of the aforementioned metrics of skill requirements of jobs is desirable for the purposes of our study, given that the focus is on whether task complexity has any significant explanatory power on the variation of skill needs between 'otherwise similar' jobs. Following the above-mentioned methodologies, the distribution of skill needs in our study is proxied by what may be considered as 'normal' ranges of skill levels and utilisation, obtained by individual-job pairs where the skills of persons are well-matched to or wellexploited in their jobs. In this manner, the analysis is not distorted by the presence of individuals whose level of skill diverges from what is required (i.e. either over- or underskilled), or whose skill use is unusually high or low with respect to what one would expect for their skill level. Utilising this methodology, the final sample is therefore further reduced to include only cases of individuals who have skills matched to what is typically required by their jobs. For both of the numeracy and literacy skill domains it is found that the level and use of skills falls within the range of typical skill requirements for about $81-83 \%$ of the sample of employees (approximately 65-66 thousand cases).

\subsection{Summary statistics}

Table 2 displays descriptive statistics for some of the key variables of interest, in particular breakdowns for the main dependent variables used in the empirical analysis of the paper. It is evident that, on average, jobs that entail a higher frequency of abstract tasks, or those that involve a greater degree of latitude and interactivity in tasks, are associated with a higher level of skill requirements and a greater degree of skill utilisation. The reverse holds for jobs that depend more frequently on the execution of physical tasks.

The summary statistics also reveal that there is marked heterogeneity in skill requirements and levels of skill use across jobs, even if these jobs are grouped under the same occupational or industrial titles, which are typically used in economics research as proxies of skill 
demand. ${ }^{16}$ For instance, individuals employed in occupations classified as 'Managerial' or 'Professional' need to possess a higher average level of skills to do their jobs relative to those in 'Skilled agriculture' or 'Elementary' occupations. Similarly, the mean level of skill demand is higher in the 'Information and Communication' or 'Finance and Insurance' industries compared to employees in 'Agriculture and Manufacturing'. Nevertheless, it is evident that there is significant variance in skill needs within these conventional occupational and industrial categories. The level of skill demand is also observed to be greater in largersized workplaces. Furthermore, there is an inverse U-shaped relationship with age, implying that prime-aged individuals are employed in more skill-intensive jobs, while individuals with higher levels of formal qualifications are also more likely to be in jobs with higher skill content. ${ }^{17}$ Jobs with more stringent hiring requirements in terms of formal educational credentials are also characterised by higher cognitive skill needs.

\section{[INSERT TABLE 2 ABOUT HERE]}

Table 2 highlights that to decouple the independent influence of job design on skill needs, it is necessary to account for the aforementioned job and individual characteristics. The variance of different tasks across jobs is correlated with these variables, for instance the frequency of abstract tasks and of job latitude tends to be higher in certain occupations or industries, while there is also significant cross-country variation in the pooled sample.

\section{Empirical methodology and main findings}

Following the methodology, as described in the previous section, for approximating skill demand and skill use, we have firstly used the information on individuals' assessed competences from the PIAAC dataset in order to establish whether individuals' skills are matched to their jobs. The analysis subsequently exploits the heterogeneity in the objectivelymeasured skill levels of matched individuals, namely those who have well-matched/wellutilised skills in their jobs, as a proxy for the variance of skill demand across different jobs. ${ }^{18}$ The robustness of the procedure has been assessed by using various criteria or thresholds to establish whether individuals' skills are matched to their jobs.

\footnotetext{
${ }^{16}$ Although the table illustrates summary statistics for literacy skill requirements, similar patterns are observed in the data with respect to numeracy skills.

17 The terms 'skill requirements', 'skill needs', 'skill intensity' and 'skill content' of jobs are used interchangeably in the paper.

${ }^{18}$ Although the PIAAC survey collects information on skills at the individual level, the procedure used in the paper treats the specific ‘job’ occupied by an individual in the sample as the primary unit of analysis.
} 
Given the continuous nature of the dependent variables (i.e. numeracy and literacy skill requirement scales) the relationship between job complexity and skill needs is empirically estimated using ordinary least squares, on the basis of the following empirical specification: ${ }^{19}$

$$
S_{D j s}=\alpha+\beta_{1} T_{j}+\beta_{2} X_{j}+\beta_{3} C_{j}+\varepsilon_{j}
$$

where $S_{D}$, the demand for a given cognitive skill domain $s$ (i.e. literacy, numeracy) in a job, $j$, is modelled as a linear function of task design $(T)$ and of other job/individual characteristics $(\mathbf{X})$. Country dummy variables $(C)$ are also included in the specification to purge the effect of country-specific effects that may account for the variation in skill needs. $\varepsilon \sim N\left(0, \sigma^{2}\right)$ is a Gaussian random disturbance term assumed to be identically and independently distributed. In all empirical estimations robust standard errors clustered at the country level are estimated.

The set of regression controls (X) included in the analysis first takes into account a number of demand-side characteristics, namely variables descriptive of individuals' jobs: sector of economic activity (NACE), broad occupational groups (1-digit ISCO), type of organization (i.e. public, private, non-profit), workplace size, whether the workplace is part of a larger organisation, usual weekly hours associated with the job, if the job is contracted for a temporary duration ${ }^{20}$, if it entails supervisory duties or if formal or non-formal training is provided. Individual (i.e. supply side) characteristics have also been considered as follows: age, gender, highest level of educational attainment, total labour market experience ${ }^{21}$ and attitudes to learning. ${ }^{22}$

In a partial equilibrium framework a positive correlation between task complexity and skill needs is likely to capture the endogenous allocation of higher skilled individuals to complex tasks, in accordance with their comparative advantage in the performance of such tasks and higher (expected) market returns. To isolate the effect of job tasks on skill demand and to ensure that the relation is not mediated by the greater supply of highly skilled applicants, the empirical estimation has also taken into account the formal recruitment criteria

\footnotetext{
${ }^{19}$ A random intercept multilevel model (MLM) has also been estimated that takes into account the country-level variation in skill needs in the pooled sample. However, a likelihood ratio test rejects the hypothesis of significant differences between the MLM estimates and those of a linear regression.

${ }^{20}$ A temporary post used as a means of addressing short-term business needs is likely to be less critical for the continued operation of an establishment and will, thus, entail lower skill needs (Pellizzari 2011).

${ }^{21}$ The analysis has also included employer tenure as a regressor, given that job complexity is likely to be correlated with the years an individual is employed in his/her job. However, it was omitted from the final empirical specification due to its collinearity with the variable 'total labour market experience'.

${ }^{22}$ Whether the job holder is a native speaker has also been taken into account, but it is not included in the final specification as the information is not available for Austria.
} 
(usual qualifications and years of work experience) needed by current job applicants to be hired in the job.

The descriptive statistics for the covariates included in the regression can be found in Table A1 in the Annex.

In order to estimate equation (1), different approaches have been followed that aim to identify a match between workers' skills and job requirements. These approaches enable us to map the information on the assessed skill levels of workers onto a given value of a skill requirement per job, thus identifying the population of interest for the purposes of the main empirical analysis (i.e. the distribution of skill needs of jobs in each country).

The results based on the skill domain of literacy are presented in Table $3 .^{23}$ First, the distribution of skill needs is approximated by focusing on individuals with skills matched to their job duties based on their own subjective assessment (Model 1). One may argue that it is the individual job holders themselves who are in possession of the best information set concerning the correspondence of their skills with the tasks required by their jobs. The regression shows that jobs rich in abstract reasoning and those that allow for greater job latitude, as opposed to jobs involving physical work, are characterised by higher skill requirements.

The self-reported measure of skills matching, used in Model 1, may be subject to selfreporting bias and it relies on a highly truncated sample. For this reason, the analysis is extended to include a wider sample of individuals whose skills fall within a typical 'range of matched skills' in their occupation, as inferred by the OECD approach described in section 3. This methodology classifies individuals as matched if their assessed skill level falls within a band, defined by the minimum and maximum skill needs of their own occupation (Models 2, 3 and 4). Model 2 confirms that the demand for literacy skills is higher in jobs that entail a greater degree of autonomy and frequency of abstract reasoning tasks, while it decreases in the frequency of physical tasks. Model 3 shows that these results are robust to the introduction of individual worker controls.

Job design is likely to be correlated with other characteristics of the firms in which individuals are employed, such as business and product market strategy, the technological frontier of production, the quality of industrial relations and other HR practices. It is thus

${ }^{23}$ The regression estimates for the domain of numeracy skills are provided in Table A2 in the Annex. 
expected that the coefficient on $T$ may overestimate the impact of job tasks on skill requirements. ${ }^{24}$

To take some of these endogenous influences into account, the empirical specification further considers the extent to which a job involves learning work-related things from colleagues and supervisors (a proxy for the interpersonality of work relations and the extent of informal learning in the workplace); the frequency of having to keep up to date with new products and services (a proxy for the product market strategy of the individual's employer); and the level of computer use (i.e. basic, moderate or advanced) needed to perform the job (a proxy for the technological frontier of the job). Moreover, the hourly earnings for wage and salary earners has also been considered in the regression framework as a further robustness check, although it is clear that this variable is endogenously related to both job tasks and skills. However, to the extent that the wage can be considered a posted wage (Hall and Krueger 2012; Brenzel et al. 2014), it would reflect the overall ability of the organization to pay for skills. Model 4 shows that the main empirical relation between job tasks and skill demand is robust to the introduction of the aforementioned additional organizational variables. This is true even if the magnitude of the estimated coefficients is somewhat reduced, as part of the effects is captured by the inclusion of these additional variables in the regression framework.

Finally, the estimation is replicated on a sample of jobs in which individuals' skills are effectively used, the extent of skill use measured via the self-reported frequency of tasks scales available in the PIAAC survey (Model 5). ${ }^{25}$ Although this derived variable is not, strictly speaking, a measure of the distribution of required skill levels across diverse jobs, it captures the extent to which an individual's use of skills falls within a range that is normal for a person with a comparable skill level (Allen et al. 2013).

In contrast to the positive impact of abstract reasoning and of job latitude on the skill requirements of jobs, mixed effects are found for jobs that differ according to whether they involve a higher frequency of interactive tasks with clients or co-workers. While such jobs are found to be correlated with a better utilisation of workers' skills they are, nonetheless, associated with jobs of a lower cognitive skill level. ${ }^{26}$

\footnotetext{
${ }^{24}$ At the same time and to the extent that tasks are measured with error the coefficient on $\mathrm{T}$ will be biased toward zero and will tend to produce a conservative estimate of the impact of tasks on skill requirements.

${ }^{25}$ An alternative estimation approach is to model the conditional distribution of skill use relative to the assessed skill level of an individual i.e. $G$ (skill use|skill level). Adopting such an approach confirms the empirical estimates as reported in section 5 . The results are available from the authors upon request.

${ }^{26}$ The empirical results also bear out that required literacy and numeracy levels increase with the size of the workplace and are positively related to the provision of (formal or non-formal) training opportunities as part of
} 


\section{[INSERT TABLE 3 ABOUT HERE]}

\section{Robustness checks}

To check the robustness of the positive relationship between task complexity and skill requirements, as shown in Table 3, equation (1) has been estimated using a more refined occupational classification at the 2-digit level in the control set. ${ }^{27}$ It is generally observed in the PIAAC dataset that there is significant heterogeneity in the assessed skill levels of individuals and, by extension, in the skill requirements of jobs within 1-digit occupational groups. Table 4 confirms that the statistically significant positive coefficients of abstract reasoning and job latitude persist in spite of the inclusion of a finer occupational granularity in the regression. ${ }^{28}$

\section{[INSERT TABLE 4 ABOUT HERE]}

Moreover, the measure of skill requirements based on the OECD approach has been reconstructed so that the minimum and maximum thresholds of skills, which define whether an individual's literacy skills are matched to those required by his/her job, are derived on the basis of the more detailed 2-digit occupational groups. This is done because the main OECD measure of skill requirements used in Table 3 has been criticised, on the grounds that it reduces the heterogeneity of skill demand to a small number of broad (1-digit) occupational categories (Allen et al. 2013).

In particular, the distribution of the assessed literacy skills of well-matched individuals has been extracted for each country and 2-digit occupational group separately. ${ }^{29}$ Employees are subsequently deemed to have a literacy skill level that is matched to what their job requires if their assessed level falls within the 'typical skills band' of their respective 2-digit occupational group. Following this methodology, the sample of employees with matched skills (which is a proxy for skill needs) falls to $76 \%$, as opposed to $83 \%$ which was the case with the original OECD measure. Despite this new construct, the regression coefficients in

the job. The estimates show that individuals with higher educational qualifications and positive attitudes to learning are in jobs with high skill requirements. Also jobs requiring more years of education on behalf of current job applicants tend to be characterized by high skill requirements

${ }^{27}$ For the sake of space constraints, Table 4 only reports the outcome of the robustness tests for the skill domain of literacy. The respective estimations for numeracy are available from the authors upon request.

${ }^{28}$ Given the limited number of observations, the regression has been executed under the condition that 2-digit occupational groups with at least 100 observations in each cell are taken into account. In addition, information at the 2-digit occupational level only exists for 18 OECD countries, so 4 countries (Austria, Canada, Estonia and Finland) have been dropped from the analysis.

${ }^{29}$ As before, the condition that there are at least 10 observations in each cell has been applied. 
Table 4 confirm that the positive and statistically significant impact of complex job design on skill demand is robust.

Column (5) in Table 4 also contains the results of an additional test undertaken to confront concerns about the potential lack of representativeness of the main empirical relation estimated in Table 3. In particular, it may be argued that sample selection bias could arise due to the fact that the main regression omits cases where the informational content of people's skills could not be directly translated to a measure of the skill content of their jobs. This is true for individuals classified as either overskilled or underskilled for their jobs, for whom it is not feasible to make a direct mapping of their assessed skills to the level required by their job. Given that the non-matched part of the sample comprises of $17 \%$ of the total population of adult employees in the 22 countries, we have investigated whether this missing sample could potentially affect the main regression estimates.

Selectivity bias could influence the main empirical relation if the complexity of job tasks and other job characteristics were non-randomly distributed between workers with matched and non-matched skills. A cursory review of the distribution of the observable job characteristics in the data across the different categories of workers (matched, underskilled and overskilled) reveals some, albeit limited, differences. For instance, underskilled workers are more likely to be concentrated in high-skilled occupational groups (e.g. $24.5 \%$ are Professionals as opposed to $17 \%$ of matched workers), whereas the overskilled have a greater concentration towards semi- or low-skilled occupations (e.g. $20 \%$ are in market sales and services and $11 \%$ in elementary jobs, in contrast to $17 \%$ and $7 \%$ for the matched, respectively). Employees with matched skills also have a greater tendency to be employed in the public sector (31\%, whereas the same holds for $27 \%$ of the overskilled and $28 \%$ of the underskilled).

To take the truncated part of the sample into account, we have therefore used the values of the upper (for the overskilled) and the lower (for the underskilled) threshold of skills within each individual's occupation as a proxy for the skill content of their job. The main regression of cognitive skill demands on the nature of task complexity within people's jobs has been subsequently repeated, albeit with coverage of the entire sample of jobs of the employee workforce of the 22 countries. As can be seen in the last column of Table 4, the sign and statistical significance of the regression coefficients on the variables of task complexity remains unaffected, although the size of the effects is reduced.

Finally, in order to explore the heterogeneity in the estimated effect further, the impact of task complexity on skill needs has been estimated per each 2-digit level occupational group. 
A statistically significant coefficient of task complexity within such detailed job groupings, clearly defined according to the similarity of the tasks and duties performed, would reinforce the argument that there can be markedly different skill requirements between firms that employ varied job design principles.

Table A3 in the Appendix displays the estimated OLS regression coefficients of the relation between job design and skill demands in each of 23 occupational groups. For the purposes of statistical validity, the analysis has been constrained to include only groups with at least 1000 observations in total (across all countries in the sample). Even when focussing on more homogeneous groups of professions, such as science and engineering professionals or personal care workers, a statistically significant positive effect of abstract reasoning and of job latitude prevails in the majority of cases.

\section{Conclusions}

This paper set out to establish a significant link between job complexity and the skill demand and skill utilisation of jobs. The heterogeneity of job complexity in advanced economies has been articulated via the adoption of four constructs, which describe people's daily activities at work according to the frequency of abstract reasoning, employee latitude, interactivity and physical work. The skill content of jobs has been operationalised by focusing the analysis on jobs in which workers' skills are matched to the level that is required to perform them.

Using rich information collected as part of the recent OECD-PIAAC survey, the empirical analysis in this paper has confirmed that there exists a positive and statistically significant link between the degree of task complexity and the cognitive skill requirement of jobs. As the empirical methodology controls for the formal levels of human capital and the learning disposition of workers, who tend to be attracted to more complex jobs, as well as other important variables that mediate the relationship, it is confirmed that task complexity exerts an independent influence on skill demand both between and within occupations.

Several unobserved organizational characteristics may affect the skill content of jobs, so the results presented in this paper should be treated as associations. The recent HRM literature has advanced a dynamic vision of job design that sees workers playing an active role in shaping (crafting) their jobs (and the tasks included). In this case, the analysis in the paper would suffer from reverse causation and the link found would reflect the ability of skilled workers to craft their jobs (Berg et al. 2013; Nielsen 2013). However, there is little empirical support for this thesis. HR departments of organizations usually have a tight control 
on the way that jobs are designed and the process of bundling tasks to jobs usually constitutes the starting point of the job crafting process (and any changes take place at the margin). Moreover, while some personal characteristics have been associated with an individual inclination to craft own jobs, no significant correlation has been found between cognitive ability and the likelihood of engaging in the job crafting process (Lyons 2008). The HRM literature has also tended to characterise workers' inclination towards the personalization of the set of their job tasks though specific avenues: (i) Extra Role Behaviour (taking up additional tasks outside the workers' role in the organization) (Van Dyne et al. 1995); (ii) Organizational citizenship behaviour - taking up additional tasks to help colleagues (Organ 1997; Organ et al. 2006), and (iii) Contextual performance (Borman and Motowidlo 1993; Motowidlo and Van Scotter 1994). A cursory review of the literature (mainly based on the US labor market) reveals that personality traits are generally linked to these behaviours rather than cognitive ability (Morgeson et al. 2005; Bakker et al. 2012) .

Our paper has interesting policy implications. With the marked rise in educational attainment in developed countries and with the generalized increase in the supply of skills, more attention should be paid by policy makers to the issue of skills utilisation in addition to policies that promote further skill development (e.g. training). This requires policies that will support organizations in their adoption of more advanced business and product strategies and encourage them to adopt more complex job design (Sung and Ashton 2015). This is a worthy policy objective since, while some organizations make full use of the skills in their workforce, others "through inertia, lack of understanding or philosophical reluctance, remain ignorant of the benefits of smart working and the performance improvement that it can bring” (CIPD 2008). Maitland and Thomson (2011) also argue that, despite the benefits the HPW, the diffusion of such practices across organisations can be slow given that "old habits die hard" and since some employers are unwilling to "shift in culture and mindset”. In light of the enormous variation in managerial practices that is reported in the literature (Bloom and Van Reenen 2007; Bloom and Van Reenen 2010; Eurofound 2011; Syverson 2011; Eurofound 2012; Card, Heining et al. 2013), it therefore becomes clear that there is wide scope for supporting organizations in designing better and smarter jobs. 


\section{References}

Acemoglu, D. and D. Autor (2011). 'Skills, Tasks and Technologies: Implications for Employment and Earnings’. Handbook of Labor Economics. D. Card and O. Ashenfelter. Amsterdam, Elsevier. Volume 4, Part B: 1043-1171.

Allen, J., Levels, M. and van der Velden, R. (2013), 'Skill mismatch and use in developed countries: Evidence from the PIAAC study', RM/13/060, Maastricht university.

Applebaum, E., Bailey, T. and Berg, P. (2000) Manufacturing advantage: why high performance work systems pay off. Ithaca, NY: Cornell University Press.

Ashton, D. and Sung, J. (2011), 'Product market strategies and skill utilisation', Skills in focus, Skills development Scotland.

Autor, D. H. and M. J. Handel (2013). "Putting Tasks to the Test: Human Capital, Job Tasks, and Wages." Journal of Labor Economics 31(2): S59-S96.

Autor, D. H., F. Levy, et al. (2003). "The Skill Content of Recent Technological Change: An Empirical Exploration." The Quarterly Journal of Economics 118(4): 1279-1333.

Bakker, A. B., M. Tims, et al. (2012). "Proactive personality and job performance: The role of job crafting and work engagement." Human Relations 65(10): 1359-1378.

Bauer, T. (2004). High Performance Workplace Practices and Job Satisfaction: Evidence from Europe. RWI : Mitteilungen, Vol. 54/55, No. 1, p. 57-85.

Berg, J. M., J. E. Dutton, et al. (2013). Job Crafting and the meaning of work. Purpose and Meaning in the Workplace. B. J. Dik, Z. S. Byrne and M. F. Steger, American Psychological Association.

Bloom, N. and J. Van Reenen (2007). "Measuring and Explaining Management Practices Across Firms and Countries." The Quarterly Journal of Economics 122(4): 1351-1408.

Bloom, N. and J. Van Reenen (2010). "Why Do Management Practices Differ across Firms and Countries?" The Journal of Economic Perspectives 24(1): 203-224.

Bloom, N. and J. Van Reenen (2011). Human Resource Management and Productivity. Handbook of Labor Economics. C. David and A. Orley, Elsevier. Volume 4, Part B: 1697-1767.

Borman, W. C. and S. J. Motowidlo (1993). Expanding the criterion domain to include elements of contextual performance. Personnel Selection in Organizations. N. Schmitt and W. C. Borman. San Francisco, Jossey-Bass.

Brenzel, H., Gartner, H., et al. (2014). "Wage bargaining or wage posting? Evidence from the employers' side." Labour Economics 29: 41-48.

Buchanan, J., et al. (2010), "Skills Demand and Utilisation: An International Review of Approaches to Measurement and Policy Development", OECD Local Economic and Employment Development (LEED) Working Papers, No. 2010/04, OECD Publishing, Paris.

Card, D., J. Heining, et al. (2013). "Workplace Heterogeneity and the Rise of West German Wage Inequality." The Quarterly Journal of Economics 128(3): 967-1015.

Caroli, E. and J. Van Reenen (2001). "Skill-Biased Organizational Change? Evidence from A Panel of British and French Establishments." The Quarterly Journal of Economics 116(4): 1449-1492.

Cedefop (2012a). Skill mismatch: the role of the enterprise. Luxembourg: Publications Office. Cedefop research paper; No 21. http://www.cedefop.europa.eu/EN/Files/5521_en.pdf

Cedefop (2012b). Future skills supply and demand in Europe: forecast 2012. Luxembourg: Publications Office. Cedefop research paper; No 26.

http://www.cedefop.europa.eu/EN/Files/5526_en.pdf 
Cedefop (2015a), Skills, qualifications and jobs: The making of a perfect match? Cedefop reference report, Office for the Official Publications of the European Communities: Luxembourg.

Cedefop (2015b). Skill shortages and skill gaps in European enterprises: Striking a balance between vocational education and training and the labour market. Cedefop Reference series.

CIPD (2008), Smart working: the impact of work organisation and job design, Research insight, London.

DTI and CIPD (2006). High Performance Work Practices: linking strategy and skills to performance outcomes. available at www.dti.gov.uk [assessed 15/09/2011].

Eurofound (2011). Management practices and sustainable organisational performance: an analysis of the European Company Survey 2009. Luxembourg, Publication Office of the European Union.

Eurofound (2012). Trends in job quality in Europe. Luxembourg, Publication Office of the European Union.

Eurofound (2014). Drivers of recent job polarisation and upgrading in Europe. Luxembourg, Publication Office of the European Union.

European Commission (2008). New skills for new jobs: anticipating and matching labour market needs: communication from the Commission to the European Parliament, the Council, the European Economic and Social Committee and the Committee of the Regions. COM (2008) 868 final. ec.europa.eu/social/BlobServlet?docId=1496\&langId=en

Fernández-Macías, E. (2012). "Job Polarization in Europe? Changes in the Employment Structure and Job Quality, 1995-2007." Work and Occupations 39(2): 157-182.

Gibbs, M., A. Levenson, et al. (2010). Why are jobs designed the way they are? Jobs, Training, and Worker Well-being. S. W. Polachek and K. Tatsiramos. London, Emerald Group. 30: 107-154.

Groot, W.; Maassen van den Brink, H. (2000). Overeducation in the labor market: a meta-analysis. Economics of Education Review, Vol. 19, No. 2, p. 149-158.

Hackman, J. R. and G. R. Oldham (1976). "Motivation through the design of work: test of a theory." Organizational Behavior and Human Performance 16(2): 250-279.

Hall, R. E. and Krueger, A. B. (2012). "Evidence on the Incidence of Wage Posting, Wage Bargaining, and On-the-Job Search." American Economic Journal: Macroeconomics 4(4): 56-67.

Handel, M. (2012), “Trends in Job Skill Demands in OECD Countries”, OECD Social, Employment and Migration Working Papers, No. 143, OECD Publishing.

Huczynski, A. and Buchanan, D. (2001) Organizational behaviour: an introductory text. 4th ed. London: Financial Times/Prentice Hall.

Huselid, M. A. (1995). "The Impact of Human Resource Management Practices on Turnover, Productivity, and Corporate Financial Performance." The Academy of Management Journal 38(3): 635-672.

Ichniowski, C. and K. Shaw (2003). "Beyond Incentive Pay: Insiders' Estimates of the Value of Complementary Human Resource Management Practices." The Journal of Economic Perspectives 17(1): 155-180.

Ichniowski, C., K. Shaw, et al. (1997). "The Effects of Human Resource Management Practices on Productivity: A Study of Steel Finishing Lines." The American Economic Review 87(3): 291-313.

Karasek, R.A. (1979). "Job demands, job decision latitude, and mental strain: Implications for job redesign", Administrative Science Quarterly, Vol. 24, 285 - 308.

Katz, L. F. and D. H. Autor (1999). Changes in the Wage Structure and Earnings Inequality. Handbook of Labor Economics. A. Orley and C. David. Amsterdam, Elsevier. Volume 3, Part A: 1463-1555. 
Lazear, E.P. (1992), The Job as a Concept, in: Performance Measurement and Incentive Compensation, W.J.Bruns (ed.). Cambridge: Harvard Business School Press.

Lazear, E.P. and Gibbs, M. (2009), Personnel Economics in Practice, NJ: John Wiley \& Sons.

Lazear, E.P.; Oyer, P. (2009), Personnel Economics, in: R.Gibbons \& Roberts, D.J. (ed.), Handbook of Organizational Economics, Princeton University Press.

Lyons, P. (2008). "The Crafting of Jobs and Individual Differences." Journal of Business and Psychology 23(1-2): 25-36.

Macduffie, J. P. (1995). "Human Resource Bundles and Manufacturing Performance: Organizational Logic and Flexible Production Systems in the World Auto Industry." Industrial and Labor Relations Review 48(2): 197-221.

Maitland, A. and Thomson, P. (2011), Future work: How businesses can adapt and thrive in the new world of work, Palgrave Macmillan: New York.

Morgeson, F. P., K. Delaney-Klinger, et al. (2005). "The Importance of Job Autonomy, Cognitive Ability, and Job-Related Skill for Predicting Role Breadth and Job Performance." Journal of Applied Psychology 90(2): 399-406.

Motowidlo, S. J. and J. R. Van Scotter (1994). "Evidence that task performance should be distinguished from contextual performance." Journal of Applied Psychology 79(4): 475-480.

Nielsen, K. (2013). "How can we make organizational interventions work? Employees and line managers as actively crafting interventions." Human Relations 66(8): 1029-1050.

OECD (2013). OECD Skills outlook 2013: first results from the survey of adult skills. Paris: OECD Publishing. http://dx.doi.org/10.1787/9789264204256-en

Organ, D. W. (1997). "Organizational Citizenship Behavior: It's Construct Clean-Up Time." Human Performance 10(2): 85-97.

Organ, D. W., P. M. Podsakoff, et al. (2006). Organizational Citizenship Behavior. Its nature, antecedents, and consequences. Thousand Oaks, Sage Publications.

Pellizzari, M. (2011). Employers' Search and the Efficiency of Matching. British Journal of Industrial Relations, Vol. 49, No. 1, p. 25-53.

Pellizzari, M. and A. Fichen (2013), "A New Measure of Skills Mismatch: Theory and Evidence from the Survey of Adult Skills (PIAAC)", OECD Social, Employment and Migration Working Papers, No. 153, OECD Publishing, Paris.

Pouliakas, K. (2012), 'The skill mismatch challenge in Europe’, Ch. 6 in: EU Commission (2012), Employment and social developments in Europe, Luxembourg: Publications Office.

Pouliakas, K. and I. Theodossiou (2013). "The economics of health and safety at work: an interdisciplinary review of the theory and policy." Journal of Economic Surveys 27(1): 167-208.

Prendergast, C. J. (1995). "A Theory of Responsibility in Organizations." Journal of Labor Economics 13(3): 387-400.

Sloane, P. J., et al. (1999). Overeducation, undereducation and the British labour market. Applied Economics, Vol. 31, No. 11, p. 1437-1453.

Spitz-Oener, A. (2006). "Technical Change, Job Tasks, and Rising Educational Demands: Looking outside the Wage Structure." Journal of Labor Economics 24(2): 235-270.

Stahl, F. (2013). Worker leadership. Cambridge, Massachuttes, MIT press.

Sung, J. and Ashton, D. N. (2015). Skills in business. The role of business strategy, sectoral skills development and skills policy. Thousand Oakes, Sage.

Syedain, H. (2007) A talent for numbers. People Management. Vol 13, No 12, 14 June. pp36-38 
Syverson, C. (2011). "What Determines Productivity?" Journal of Economic Literature 49(2): 326365.

UKCES (2008), Skills for the workplace: Employer perspectives, Evidence report No. 1, November.

UKCES (2009). High performance working: a synthesis of key literature. London: UK Commission for Employment and Skills. Evidence report; No 4, August.

UKCES (2011). Product strategies, skills shortages and skill updating needs in England: new evidence from the national employer skills survey, 2009. London: UKCES, UK Commission for Employment and Skills. Evidence report; No 30, July.

Van Dyne, L., L. L. Cummings, et al. (1995). Extra role behaviors: in pursuit of construct and definition clarity. Research in Organizational Behavior. L. L. Cummings and B. M. Staw. Greenwich, CT, JAI Press. 17: 215-285.

Whitfield, K. (2000), 'High-Performance Workplaces, Training, and the Distribution of Skills', Industrial Relations, Vol. 39, No. 1, pp. 1-25.

Wright, P.M., McMahan, G.C. and McWilliams, A. (1994). Human resources and sustained competitive advantage: a resource-based perspective. The International Journal of Human Resource Management, 5: 301-326. 
Table 1 Indicators of task complexity and of frequency of job tasks

\begin{tabular}{|c|c|}
\hline Type of tasks in job & $\begin{array}{l}\text { Cronbach's } \\
\text { alpha scale } \\
\text { reliability } \\
\text { coefficient }\end{array}$ \\
\hline Abstract reasoning & 0.7 \\
\hline $\begin{array}{l}\text { How often are you usually...? } \\
\text { - Faced by relatively simple problems that take no more than } 5 \text { minutes to find a good } \\
\text { solution; } \\
\text { - Confronted with more complex problems that take at least } 30 \text { minutes to find (think of) a } \\
\text { good solution. }\end{array}$ & \\
\hline Job latitude \& control & $0.8 *$ \\
\hline $\begin{array}{l}\text { To what extent can you choose or change...? } \\
\text { - the sequence of your tasks; } \\
\text { - how to do your work; } \\
\text { - the speed or rate at which you work; } \\
\text { - your working hours. } \\
\text { How often does your job usually involve...? } \\
\text { - Plan your own activities; } \\
\text { - Organise your own time. }\end{array}$ & \\
\hline Interaction \& influence & $0.8 * *$ \\
\hline $\begin{array}{l}\text { In your job, what proportion of your time do you usually spend...? } \\
\text { - Cooperating or collaborating with co-workers; } \\
\text { How often does your job usually involve...? } \\
\text { - Sharing work-related information with co-workers; } \\
\text { - Instructing, training or teaching people, individually or in groups; } \\
\text { - Making speeches or giving presentations in front of five or more people; } \\
\text { - Selling a product or selling a service; } \\
\text { - Advising people; } \\
\text { - Plan the activities of others; } \\
\text { - Persuading or influencing people; } \\
\text { - Negotiating with people either inside or outside your firm or organisation. }\end{array}$ & \\
\hline Physical work & \\
\hline $\begin{array}{l}\text { How often does your job usually involve...? } \\
\text { - Working physically for a long period }\end{array}$ & \\
\hline
\end{tabular}

Notes: In your job, what proportion of your time do you usually spend on...? $1=$ None of the time $\rightarrow 5=$ All of the time; How often does your job usually involve...? 1 = never $\rightarrow 5=$ Every day; To what extent can you choose or change...? ...? $1=$ Not at all $\rightarrow 5$ = To a very high extent. * correlation coefficient with OECD’s (2013) measure of task discretion $=0.8$; ** correlation coefficient with OECD's (2013) measure of influence $=0.9$; Source: OECD Survey of Adult Skills (PIAAC) 
Figure 1 Distribution of assessed literacy skills and skill requirements by occupation
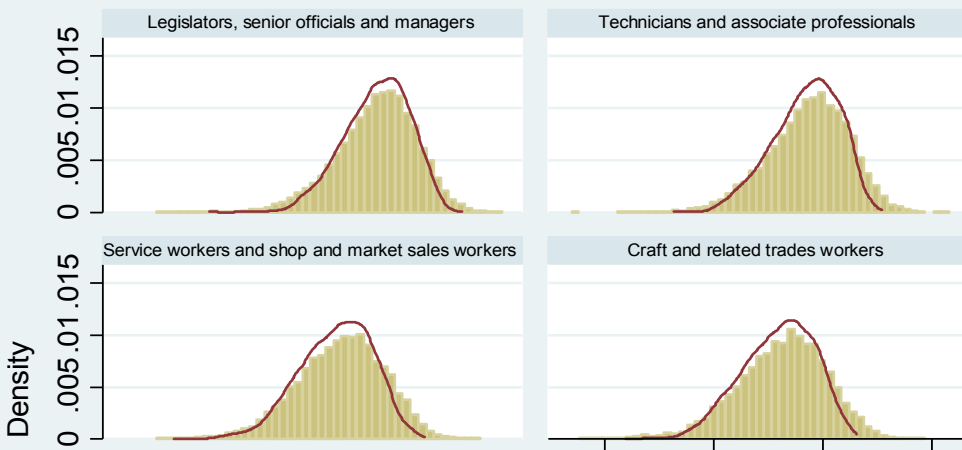

Craft and related trades workers
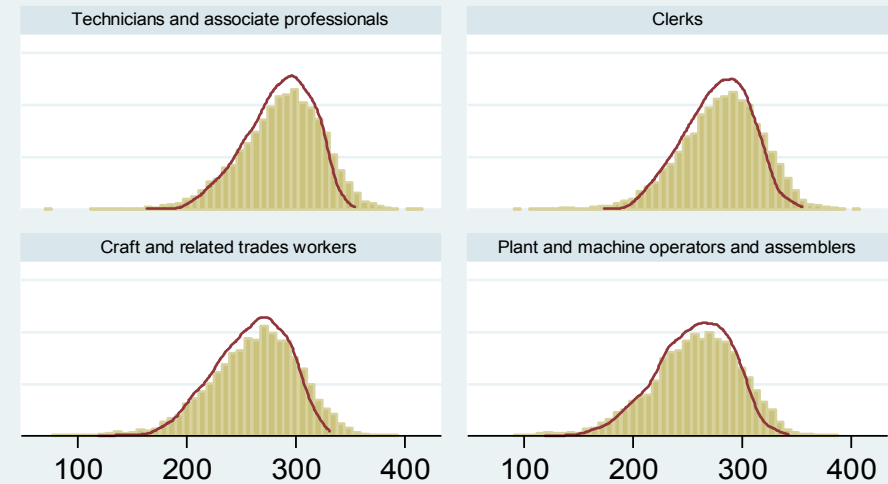

Plant and machine operators and assemblers
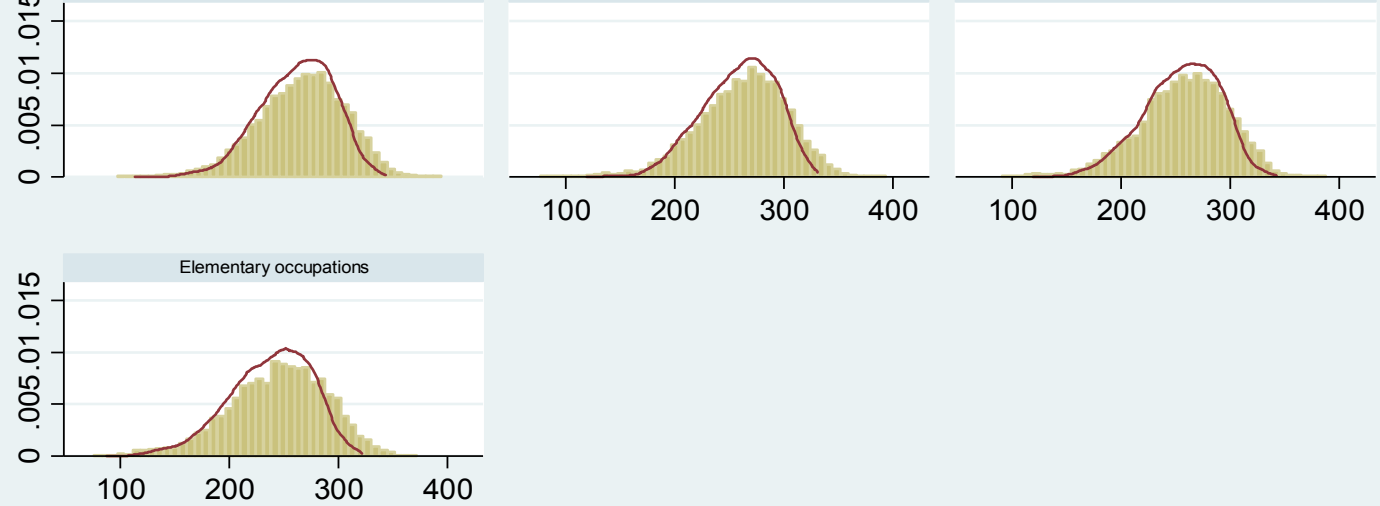

Literacy skills

Literacy skill requirements

Graphs by isco 1-digit

Notes: Literacy skill requirements are based on the distribution of assessed literacy test scores of individuals with matched skills in each occupational group, as derived using the OEDC approach. ISCO1 and ISCO2 categories have been merged while ISCO6 has been dropped due to limited sample sizes.

Source: OECD Survey of Adult Skills (PIAAC) 
Table 2 Summary statistics (mean, s.d), skill needs and use by key variables

\begin{tabular}{|c|c|c|c|c|}
\hline & \multicolumn{3}{|c|}{ Literacy skill requirements } & \multirow{2}{*}{$\begin{array}{c}\begin{array}{c}\text { Literacy } \\
\text { skill use }\end{array} \\
\text { Mean } \\
\text { (s.d) }\end{array}$} \\
\hline & $\begin{array}{l}\text { Mean } \\
\text { (s.d) }\end{array}$ & Min & $\operatorname{Max}$ & \\
\hline \multicolumn{5}{|l|}{ By task frequency } \\
\hline Abstract: High & $\begin{array}{l}286.1 \\
(34.8) \\
\end{array}$ & 122.6 & 377.9 & $\begin{array}{c}3.1 \\
(0.7) \\
\end{array}$ \\
\hline Abstract: Low & $\begin{array}{l}269.3 \\
(38.3)\end{array}$ & 88.2 & 373.0 & $\begin{array}{c}2.4 \\
(0.8)\end{array}$ \\
\hline Latitude: High & $\begin{array}{l}287.7 \\
(34.9)\end{array}$ & 106.0 & 377.9 & $\begin{array}{c}3.1 \\
(0.7)\end{array}$ \\
\hline Latitude: Low & $\begin{array}{l}271.0 \\
(37.9)\end{array}$ & 88.2 & 372.9 & $\begin{array}{c}2.6 \\
(0.8)\end{array}$ \\
\hline Interaction: High & $\begin{array}{l}286.2 \\
(33.7)\end{array}$ & 147.9 & 372.5 & $\begin{array}{c}3.3 \\
(0.6)\end{array}$ \\
\hline Interaction: Low & $\begin{array}{l}274.9 \\
(38.2) \\
\end{array}$ & 88.2 & 377.9 & $\begin{array}{c}2.6 \\
(0.8)\end{array}$ \\
\hline Physical: High & $\begin{array}{l}262.5 \\
(36.9) \\
\end{array}$ & 88.2 & 366.9 & $\begin{array}{c}2.4 \\
(0.8)\end{array}$ \\
\hline Physical: Low & $\begin{array}{l}288.9 \\
(34.0)\end{array}$ & 107.2 & 377.9 & $\begin{array}{c}3.0 \\
(0.7)\end{array}$ \\
\hline \multicolumn{5}{|l|}{ By occupation } \\
\hline Legislators, senior officials and managers & $\begin{array}{l}297.0 \\
(31.0)\end{array}$ & 185.2 & 377.9 & $\begin{array}{c}3.4 \\
(0.5)\end{array}$ \\
\hline Professionals & $\begin{array}{l}300.9 \\
(29.5)\end{array}$ & 146.1 & 374.0 & $\begin{array}{c}3.2 \\
(0.6)\end{array}$ \\
\hline Technicians and associate professionals & $\begin{array}{l}284.7 \\
(30.4)\end{array}$ & 163.1 & 354.1 & $\begin{array}{c}3.0 \\
(0.6)\end{array}$ \\
\hline Clerks & $\begin{array}{l}277.6 \\
(30.2) \\
\end{array}$ & 173.7 & 355.4 & $\begin{array}{c}2.9 \\
(0.7)\end{array}$ \\
\hline Service workers and shop and market sales workers & $\begin{array}{l}262.2 \\
(33.9)\end{array}$ & 113.4 & 343.3 & $\begin{array}{c}2.4 \\
(0.8)\end{array}$ \\
\hline Skilled agricultural and fishery workers & $\begin{array}{l}232.1 \\
(39.7)\end{array}$ & 94.6 & 313.4 & $\begin{array}{c}2.1 \\
(0.9)\end{array}$ \\
\hline Craft and related trades workers & $\begin{array}{l}258.5 \\
(33.6) \\
\end{array}$ & 118.9 & 331.1 & $\begin{array}{c}2.3 \\
(0.8) \\
\end{array}$ \\
\hline Plant and machine operators and assemblers & $\begin{array}{l}255.6 \\
(34.6)\end{array}$ & 119.1 & 343.0 & $\begin{array}{c}2.1 \\
(0.7)\end{array}$ \\
\hline Elementary occupations & $\begin{array}{l}237.5 \\
(37.8) \\
\end{array}$ & 88.2 & 322.4 & $\begin{array}{c}1.7 \\
(0.7)\end{array}$ \\
\hline \multicolumn{5}{|l|}{ By sector } \\
\hline Agriculture, forestry, fishing & $\begin{array}{l}268.2 \\
(38.9)\end{array}$ & 119.1 & 358.4 & $\begin{array}{c}2.6 \\
(0.9)\end{array}$ \\
\hline Manufacturing & $\begin{array}{l}273.9 \\
(37.2) \\
\end{array}$ & 137.0 & 367.4 & $\begin{array}{c}2.6 \\
(0.9)\end{array}$ \\
\hline Construction & $\begin{array}{l}268.6 \\
(36.0) \\
\end{array}$ & 112.1 & 377.8 & $\begin{array}{c}2.6 \\
(0.8)\end{array}$ \\
\hline Wholesale \& retail trade & $\begin{array}{l}268.1 \\
(38.1) \\
\end{array}$ & 120.5 & 372.5 & $\begin{array}{c}2.5 \\
(0.8)\end{array}$ \\
\hline Transportation \& storage & $\begin{array}{l}279.6 \\
(37.5) \\
\end{array}$ & 131.8 & 368.9 & $\begin{array}{c}2.7 \\
(0.8)\end{array}$ \\
\hline Accommodation \& food service & $\begin{array}{l}284.2 \\
(38.5)\end{array}$ & 106.0 & 375.7 & $\begin{array}{c}2.9 \\
(0.8)\end{array}$ \\
\hline Information \& communication & $\begin{array}{l}294.9 \\
(33.6)\end{array}$ & 130.9 & 370.6 & $\begin{array}{c}3.2 \\
(0.7)\end{array}$ \\
\hline Financial and insurance activities & 292.3 & 88.2 & 372.9 & 3.1 \\
\hline
\end{tabular}




\begin{tabular}{|c|c|c|c|c|}
\hline & $(34.6)$ & & & $(0.7)$ \\
\hline Real estate activities & $\begin{array}{l}282.2 \\
(40.5)\end{array}$ & 124.2 & 367.7 & $\begin{array}{c}2.9 \\
(0.8)\end{array}$ \\
\hline Professional, scientific and technical activities & $\begin{array}{l}286.0 \\
(35.5)\end{array}$ & 130.5 & 373.0 & $\begin{array}{c}3.0 \\
(0.7)\end{array}$ \\
\hline Administrative and support service activities & $\begin{array}{l}286.0 \\
(36.3)\end{array}$ & 112.1 & 369.6 & $\begin{array}{c}3.0 \\
(0.8)\end{array}$ \\
\hline Public administration \& defence & $\begin{array}{l}278.7 \\
(36.1)\end{array}$ & 118.9 & 377.9 & $\begin{array}{c}2.9 \\
(0.8)\end{array}$ \\
\hline Education & $\begin{array}{l}283.3 \\
(35.4)\end{array}$ & 135.7 & 366.3 & $\begin{array}{c}2.9 \\
(0.7) \\
\end{array}$ \\
\hline Human health \& social work & $\begin{array}{l}276.4 \\
(35.5)\end{array}$ & 113.4 & 365.3 & $\begin{array}{c}2.8 \\
(0.7)\end{array}$ \\
\hline Arts, entertainment \& recreation & $\begin{array}{l}274.4 \\
(39.3)\end{array}$ & 142.5 & 362.2 & $\begin{array}{c}2.7 \\
(0.9)\end{array}$ \\
\hline Other service activities & $\begin{array}{l}264.6 \\
(43.0)\end{array}$ & 107.2 & 356.4 & $\begin{array}{c}2.4 \\
(1.0) \\
\end{array}$ \\
\hline Activities of households as employers & $\begin{array}{l}222.8 \\
(36.6)\end{array}$ & 114.6 & 281.7 & $\begin{array}{c}1.3 \\
(0.5)\end{array}$ \\
\hline Activities of extraterritorial organizations and bodies & $\begin{array}{l}271.8 \\
(33.0)\end{array}$ & 216.6 & 333.6 & $\begin{array}{c}3.0 \\
(0.8)\end{array}$ \\
\hline \multicolumn{5}{|l|}{ By firm size } \\
\hline $1-10$ & $\begin{array}{l}268.4 \\
(37.8)\end{array}$ & 88.2 & 375.7 & $\begin{array}{c}2.5 \\
(0.9) \\
\end{array}$ \\
\hline $11-50$ & $\begin{array}{l}275.9 \\
(37.3)\end{array}$ & 106.0 & 377.8 & $\begin{array}{c}2.7 \\
(0.8) \\
\end{array}$ \\
\hline $51-250$ & $\begin{array}{l}279.5 \\
(37.4)\end{array}$ & 94.6 & 370.6 & $\begin{array}{c}2.8 \\
(0.8)\end{array}$ \\
\hline $251-1000$ & $\begin{array}{l}282.7 \\
(36.6)\end{array}$ & 113.4 & 374.0 & $\begin{array}{c}2.9 \\
(0.8) \\
\end{array}$ \\
\hline$>1000$ & $\begin{array}{l}287.9 \\
(35.8) \\
\end{array}$ & 117.7 & 377.9 & $\begin{array}{c}3.0 \\
(0.7) \\
\end{array}$ \\
\hline \multicolumn{5}{|l|}{ By level of education } \\
\hline High & $\begin{array}{l}294.5 \\
(31.9)\end{array}$ & 123.4 & 377.9 & $\begin{array}{c}3.1 \\
(0.6)\end{array}$ \\
\hline Medium & $\begin{array}{l}268.6 \\
(33.8) \\
\end{array}$ & 115.2 & 377.8 & $\begin{array}{c}2.5 \\
(0.8) \\
\end{array}$ \\
\hline Low & $\begin{array}{l}242.9 \\
(38.0)\end{array}$ & 88.2 & 357.3 & $\begin{array}{c}2.0 \\
(0.8) \\
\end{array}$ \\
\hline Total sample & $\begin{array}{l}276.6 \\
(37.8) \\
\end{array}$ & 88.2 & 377.9 & $\begin{array}{c}2.7 \\
(0.8) \\
\end{array}$ \\
\hline
\end{tabular}

Notes: A high level of task frequency is defined by scores that take a value greater than 4 in the respective derived scales; Literacy skill requirements are based on the distribution of assessed literacy test scores of individuals with matched skills in each occupational group, as derived using the OEDC approach; Literacy skill use is only measured for a sample of well-matched workers, based on approach of Allen et al. (2013) (scale range $\min =1, \max =5$ ).

Source: OECD Survey of Adult Skills (PIAAC) 
Table 3 The impact of task frequency on literacy skill demand and skill use

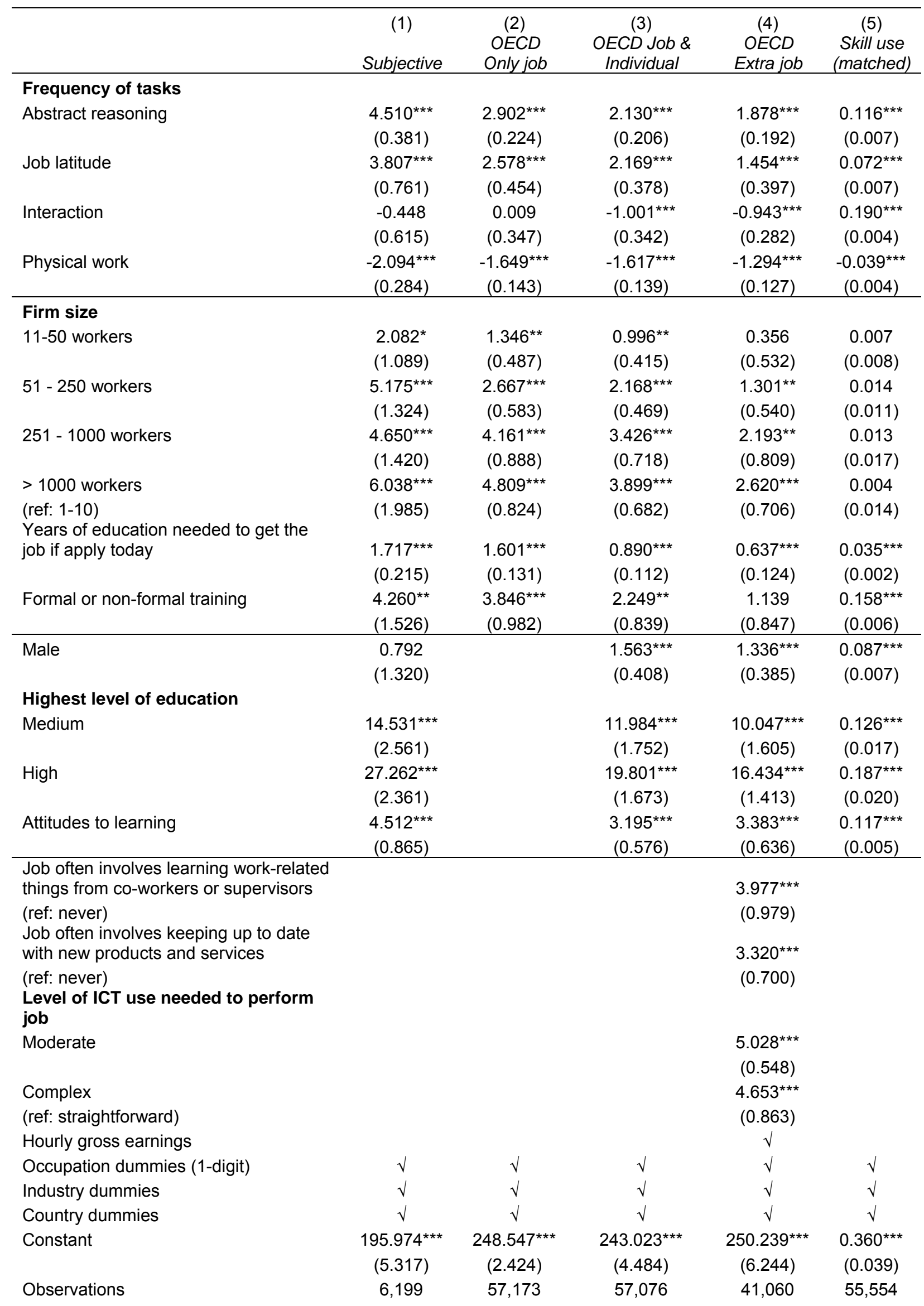


Notes: Robust standard errors in parentheses; ${ }^{* *} p<0.01,{ }^{* *} p<0.05,{ }^{*} p<0.1$; additional control variables include: type of organization (private, public, non-profit); part of larger organisation; more than 1 year of work experience needed to get job; fixed-term job; job involves supervisory duties; individual's age ( 5 age group dummies); years of paid work; usual weekly hours of work; column (4) also includes 9 dummies capturing hourly gross earnings in deciles.

Source: OECD Survey of Adult Skills (PIAAC)

Table 4: Robustness tests of the impact of task frequency on literacy skill demand

\begin{tabular}{|c|c|c|c|c|c|}
\hline & (1) & (2) & (3) & (4) & (5) \\
\hline & Subjective & $\begin{array}{c}\text { OECD } \\
\text { Job \& Individual }\end{array}$ & $\begin{array}{l}\text { Skill use } \\
\text { (matched) }\end{array}$ & $\begin{array}{l}\text { OECD } \\
\text { (defined by 2- } \\
\text { digit ISCO } \\
\text { groups) }\end{array}$ & $\begin{array}{c}\text { OECD } \\
\text { (with proxy skill } \\
\text { demand for non- } \\
\text { matched } \\
\text { workers) }\end{array}$ \\
\hline \multicolumn{6}{|l|}{$\begin{array}{l}\text { Frequency of } \\
\text { Tasks }\end{array}$} \\
\hline \multirow[t]{2}{*}{$\begin{array}{l}\text { Abstract } \\
\text { reasoning }\end{array}$} & $4.485^{\star * *}$ & $2.135^{\star * *}$ & $0.103^{* * *}$ & $2.377^{\star * *}$ & $1.919^{* * *}$ \\
\hline & $(0.522)$ & $(0.286)$ & $(0.005)$ & $(0.201)$ & $(0.164)$ \\
\hline Job latitude & $\begin{array}{l}4.147^{* \star *} \\
(0.970)\end{array}$ & $\begin{array}{l}1.874^{* * *} \\
(0.383)\end{array}$ & $\begin{array}{l}0.079^{* * *} \\
(0.005)\end{array}$ & $\begin{array}{c}2.336^{* * *} \\
(0.453)\end{array}$ & $\begin{array}{l}1.792^{* * *} \\
(0.370)\end{array}$ \\
\hline Interaction & $\begin{array}{l}-1.046 \\
(0.973)\end{array}$ & $\begin{array}{l}-0.605 \\
(0.454)\end{array}$ & $\begin{array}{l}0.198^{* * *} \\
(0.005)\end{array}$ & $\begin{array}{l}-1.187^{* * *} \\
(0.301)\end{array}$ & $\begin{array}{c}-0.936^{* * *} \\
(0.316)\end{array}$ \\
\hline Physical work & $\begin{array}{c}-1.913^{* * *} \\
(0.241)\end{array}$ & $\begin{array}{c}-1.337^{* * *} \\
(0.152)\end{array}$ & $\begin{array}{c}-0.031^{* * *} \\
(0.004)\end{array}$ & $\begin{array}{c}-1.807^{* * *} \\
(0.173)\end{array}$ & $\begin{array}{c}-1.563^{* * *} \\
(0.138)\end{array}$ \\
\hline ISCO & 2-digit & 2-digit & 2-digit & 1-digit & 1-digit \\
\hline Constant & $\begin{array}{c}219.027^{* * *} \\
(8.029)\end{array}$ & $\begin{array}{l}251.671^{* * *} \\
(7.078)\end{array}$ & $\begin{array}{l}0.469^{* * *} \\
(0.055)\end{array}$ & $\begin{array}{c}246.185^{\star * *} \\
(5.595)\end{array}$ & $\begin{array}{c}254.054^{* * *} \\
(3.016)\end{array}$ \\
\hline No of countries & 18 & 18 & 18 & 22 & 22 \\
\hline Observations & 4,371 & 38,223 & 37,857 & 52,354 & 65,517 \\
\hline R-squared & 0.466 & 0.438 & 0.633 & 0.381 & 0.360 \\
\hline
\end{tabular}

Notes: Robust standard errors in parentheses; ${ }^{* *} p<0.01,{ }^{* *} p<0.05,{ }^{*} p<0.1$; The regressions also include the full list of explanatory variables shown in Table 3.

Source: OECD Survey of Adult Skills (PIAAC) 


\section{Annex}

Table A1 Descriptive statistics of key explanatory variables, pooled sample of adult employees (aged 20-65) in 22 countries

\begin{tabular}{|c|c|}
\hline Variable & $\begin{array}{c}\text { Mean (\%) } \\
\text { (s.d.) }\end{array}$ \\
\hline \multicolumn{2}{|l|}{ Sector } \\
\hline The private sector & $66.6 \%$ \\
\hline 2 The public sector & $30.4 \%$ \\
\hline 3 A non-profit organisation & $3.0 \%$ \\
\hline \multicolumn{2}{|l|}{ Industry } \\
\hline 1 Agriculture, forestry, fishing & $6.0 \%$ \\
\hline 2 Manufacturing & $23.7 \%$ \\
\hline 3 Construction & $6.9 \%$ \\
\hline 4 Wholesale \& retail trade & $6.9 \%$ \\
\hline 5 Transportation \& storage & $4.0 \%$ \\
\hline 6 Accommodation \& food service & $3.9 \%$ \\
\hline 7 Information \& communication & $2.6 \%$ \\
\hline 8 Financial and insurance activities & $3.5 \%$ \\
\hline 9 Real estate activities & $3.6 \%$ \\
\hline 10 Professional, scientific and technical & $7.2 \%$ \\
\hline 11 Administrative and support service activities & $8.2 \%$ \\
\hline 12 Public administration \& defence & $10.8 \%$ \\
\hline 13 Education & $5.6 \%$ \\
\hline 14 Human health \& social work & $5.4 \%$ \\
\hline 15 Other service activities & $1.8 \%$ \\
\hline \multicolumn{2}{|l|}{ Occupation (1-digit) } \\
\hline 1 Legislators, senior officials and managers & $7.8 \%$ \\
\hline 2 Professionals & $21.6 \%$ \\
\hline 3 Technicians and associate professionals & $17.3 \%$ \\
\hline 4 Clerks & $10.8 \%$ \\
\hline 5 Service workers and shop and market sales & $16.7 \%$ \\
\hline 6 Skilled agricultural and fishery workers & $0.7 \%$ \\
\hline 7 Craft and related trades workers & $9.9 \%$ \\
\hline 8 Plant and machine operators and assemblers & $7.8 \%$ \\
\hline 9 Elementary occupations & $7.4 \%$ \\
\hline \multicolumn{2}{|l|}{ Workplace size } \\
\hline 11 to 10 people & $24.1 \%$ \\
\hline 211 to 50 people & $31.6 \%$ \\
\hline 351 to 250 people & $23.8 \%$ \\
\hline 4251 to 1000 people & $12.3 \%$ \\
\hline 5 more than 1000 people & $8.2 \%$ \\
\hline \multicolumn{2}{|l|}{ Part of a larger organisation } \\
\hline 1 Yes & $63.2 \%$ \\
\hline $2 \mathrm{No}$ & $36.8 \%$ \\
\hline Usual weekly hours of work & $\begin{array}{c}38.9 \\
(10.6)\end{array}$ \\
\hline Hiring requirements: Educational qualifications (years) & $\begin{array}{l}12.9 \\
(3.3)\end{array}$ \\
\hline \multicolumn{2}{|l|}{ Hiring requirements: Work experience } \\
\hline 1 None & $25.0 \%$ \\
\hline $2<1$ month & $5.1 \%$ \\
\hline
\end{tabular}




\begin{tabular}{|c|c|}
\hline $31-6$ months & $16.2 \%$ \\
\hline $47-11$ months & $7.0 \%$ \\
\hline $51-2$ years & $23.0 \%$ \\
\hline $6>3$ years & $23.8 \%$ \\
\hline \multicolumn{2}{|l|}{ Fixed-term contract } \\
\hline 1 An indefinite contract & $80.2 \%$ \\
\hline $2 \mathrm{~A}$ fixed term contract & $13.3 \%$ \\
\hline 3 A temporary employment agency contract & $1.4 \%$ \\
\hline 4 An apprenticeship or other training scheme & $0.4 \%$ \\
\hline 5 No contract & $3.7 \%$ \\
\hline 6 Other & $1.0 \%$ \\
\hline \multicolumn{2}{|l|}{ Supervisory duties } \\
\hline 1 Yes & $30.5 \%$ \\
\hline $2 \mathrm{No}$ & $69.5 \%$ \\
\hline \multicolumn{2}{|l|}{ Training (formal or non-formal education for job-related reasons in last 12 months) } \\
\hline \multicolumn{2}{|l|}{1 Yes } \\
\hline $0 \mathrm{No}$ & $52.5 \%$ \\
\hline Human capital: Highest level of educational attainment & $47.5 \%$ \\
\hline 1 Low & $12.1 \%$ \\
\hline 2 Medium & $45.1 \%$ \\
\hline 3 High & $42.8 \%$ \\
\hline Human capital: Work experience (years paid work) & $\begin{array}{c}19.4 \\
(11.9) \\
\end{array}$ \\
\hline \multicolumn{2}{|l|}{ Gender } \\
\hline 1 Male & $48.9 \%$ \\
\hline 2 Female & $51.1 \%$ \\
\hline \multicolumn{2}{|l|}{ Age groups } \\
\hline $1<24$ & $8.8 \%$ \\
\hline $225-34$ & $23.8 \%$ \\
\hline $335-44$ & $25.9 \%$ \\
\hline $445-54$ & $25.4 \%$ \\
\hline $5>55$ & $16.0 \%$ \\
\hline Attitudes to learning $(a=0.9)$ & $\begin{array}{c}3.68 \\
(0.71) \\
\end{array}$ \\
\hline Job often involves learning work-related things from co-workers or supervisors & $68.9 \%$ \\
\hline Job often involves keeping up to date with new products and services & $65.8 \%$ \\
\hline \multicolumn{2}{|l|}{ Level of ICT use needed to perform job } \\
\hline Straightforward & $32.0 \%$ \\
\hline Moderate & $60.4 \%$ \\
\hline Complex & $7.6 \%$ \\
\hline
\end{tabular}

Notes: The scale attitudes to learning is derived as a Cronbach's alpha of the following items: (i) When I hear or read about new ideas, I try to relate them to real life situations to which they might apply; (ii) I like learning new things; (iii) When I come across something new, I try to relate it to what I already know; (iv) I like to get to the bottom of difficult things; (v) I like to figure out how different ideas fit together; (vi) If I don't understand something, I look for additional information to make it clearer.

Source: OECD Survey of Adult Skills (PIAAC) 
Table A2: The impact of task frequency on numeracy skill demand

\begin{tabular}{|c|c|c|c|c|c|}
\hline & $\begin{array}{c}\text { (1) } \\
\text { Subjective }\end{array}$ & $\begin{array}{c}(2) \\
\text { OECD } \\
\text { Only job }\end{array}$ & $\begin{array}{c}(3) \\
\text { OECD Job \& } \\
\text { Individual }\end{array}$ & $\begin{array}{l}(4) \\
\text { OECD Extra } \\
\text { job }\end{array}$ & $\begin{array}{c}(5) \\
\text { Skill use } \\
\text { (matched) }\end{array}$ \\
\hline \multicolumn{6}{|l|}{$\begin{array}{l}\text { Frequency of } \\
\text { tasks }\end{array}$} \\
\hline Abstract reasoning & $\begin{array}{c}4.547^{* * *} \\
(0.404)\end{array}$ & $\begin{array}{l}3.381^{* * *} \\
(0.205)\end{array}$ & $\begin{array}{c}2.442^{* * *} \\
(0.192)\end{array}$ & $\begin{array}{l}2.137^{* * *} \\
(0.158)\end{array}$ & $\begin{array}{l}0.092^{* * *} \\
(0.005)\end{array}$ \\
\hline Job latitude & $\begin{array}{c}4.138^{* * *} \\
(0.720)\end{array}$ & $\begin{array}{c}3.171^{\star * *} \\
(0.473)\end{array}$ & $\begin{array}{c}2.626^{\star * *} \\
(0.395)\end{array}$ & $\begin{array}{c}1.412^{* * *} \\
(0.489)\end{array}$ & $\begin{array}{c}0.112^{* * *} \\
(0.006)\end{array}$ \\
\hline Interaction & $\begin{array}{l}-0.869 \\
(0.788)\end{array}$ & $\begin{array}{l}-0.471 \\
(0.336)\end{array}$ & $\begin{array}{c}-1.418^{* * *} \\
(0.349)\end{array}$ & $\begin{array}{c}-1.391^{\star * *} \\
(0.299)\end{array}$ & $\begin{array}{c}0.149^{* * *} \\
(0.006)\end{array}$ \\
\hline Physical work & $\begin{array}{c}-2.449^{* * *} \\
(0.284) \\
\end{array}$ & $\begin{array}{c}-1.994^{* * *} \\
(0.147) \\
\end{array}$ & $\begin{array}{c}-1.916^{\star * *} \\
(0.149) \\
\end{array}$ & $\begin{array}{c}-1.449^{* * *} \\
(0.129) \\
\end{array}$ & $\begin{array}{c}-0.071^{* * *} \\
(0.005)\end{array}$ \\
\hline $\begin{array}{l}\text { Control variables } \\
\text { [as in Table 3] } \\
\text { Occupation } \\
\text { dummies (1-digit) }\end{array}$ & $\sqrt{ }$ & $\sqrt{ }$ & $\sqrt{ }$ & $\sqrt{ }$ & $\sqrt{ }$ \\
\hline Industry dummies & $\sqrt{ }$ & $\sqrt{ }$ & $\sqrt{ }$ & $\sqrt{ }$ & $\sqrt{ }$ \\
\hline Country dummies & $\sqrt{ }$ & $\sqrt{ }$ & $\sqrt{ }$ & $\sqrt{ }$ & $\sqrt{ }$ \\
\hline Constant & $\begin{array}{c}183.615^{* * *} \\
(5.421)\end{array}$ & $\begin{array}{c}246.270^{* * *} \\
(2.435)\end{array}$ & $\begin{array}{c}236.634^{* * *} \\
(3.330)\end{array}$ & $\begin{array}{c}250.336^{\star \star \star} \\
(4.246)\end{array}$ & $\begin{array}{c}0.665^{* * *} \\
(0.054)\end{array}$ \\
\hline Observations & 6,199 & 57,603 & 57,505 & 41,368 & 55,336 \\
\hline R-squared & 0.488 & 0.400 & 0.439 & 0.389 & 0.444 \\
\hline
\end{tabular}

Notes: Robust standard errors in parentheses; ${ }^{* * *} p<0.01,{ }^{* *} p<0.05,{ }^{*} p<0.1$.

Source: OECD Survey of Adult Skills (PIAAC) 
Table A3 Effect of task complexity on literacy skill requirements by 2-digit occupational group

\begin{tabular}{|c|c|c|c|c|c|c|c|c|c|c|c|c|}
\hline & (1) & (2) & (3) & (4) & (5) & (6) & (7) & (8) & (9) & (10) & (11) & $(12)$ \\
\hline & $\begin{array}{c}\text { Administrative } \\
\text { and } \\
\text { commercial } \\
\text { managers }\end{array}$ & $\begin{array}{l}\text { Production } \\
\quad \text { and } \\
\text { specialised } \\
\text { services } \\
\text { managers }\end{array}$ & $\begin{array}{l}\text { Science and } \\
\text { engineering } \\
\text { professionals }\end{array}$ & $\begin{array}{c}\text { Health } \\
\text { professionals }\end{array}$ & $\begin{array}{c}\text { Teaching } \\
\text { professionals }\end{array}$ & $\begin{array}{c}\text { Business and } \\
\text { administration } \\
\text { professionals }\end{array}$ & $\begin{array}{l}\text { Legal, social } \\
\text { and cultural } \\
\text { professionals }\end{array}$ & $\begin{array}{c}\text { Science and } \\
\text { engineering } \\
\text { associate } \\
\text { professionals }\end{array}$ & $\begin{array}{c}\text { Health } \\
\text { associate } \\
\text { professionals }\end{array}$ & $\begin{array}{c}\text { Business } \\
\text { and } \\
\text { administratio } \\
\mathrm{n} \text { associate } \\
\text { professionals }\end{array}$ & $\begin{array}{l}\text { General and } \\
\text { keyboard } \\
\text { clerks }\end{array}$ & $\begin{array}{l}\text { Customer } \\
\text { services } \\
\text { clerks }\end{array}$ \\
\hline Abstract reasoning & 0.637 & 1.215 & $1.719^{*}$ & $2.223^{* * *}$ & $2.186^{\star *}$ & $2.730^{* *}$ & 0.657 & $3.197^{\star * *}$ & -0.024 & $1.476^{\star \star}$ & 0.588 & -0.711 \\
\hline \multirow[t]{2}{*}{ Job latitude } & $\begin{array}{l}(1.219) \\
3.450^{\star *}\end{array}$ & $\begin{array}{c}(1.549) \\
1.063\end{array}$ & $\begin{array}{c}(0.931) \\
0.316\end{array}$ & $\begin{array}{c}(0.756) \\
0.062\end{array}$ & $\begin{array}{l}(0.785) \\
3.728^{\star * *}\end{array}$ & $\begin{array}{l}(1.028) \\
3.585^{* \star}\end{array}$ & $\begin{array}{l}(0.906) \\
1.773^{*}\end{array}$ & $\begin{array}{l}(0.774) \\
-0.691\end{array}$ & $\begin{array}{l}(0.927) \\
2.791^{\text {** }}\end{array}$ & $\begin{array}{l}(0.558) \\
1.901^{* *}\end{array}$ & $\begin{array}{r}(0.806) \\
4.838^{* * *}\end{array}$ & $\begin{array}{c}(1.077) \\
1.742\end{array}$ \\
\hline & $\begin{array}{l}(1.590) \\
-0.002\end{array}$ & $\begin{array}{l}(1.228) \\
-2.380^{*}\end{array}$ & $\begin{array}{l}(1.000) \\
-0.242\end{array}$ & $\begin{array}{l}(0.652) \\
-0.453\end{array}$ & $\begin{array}{l}(1.034) \\
-0.944\end{array}$ & $\begin{array}{c}(1.257) \\
-3.477^{\star \star \star}\end{array}$ & $\begin{array}{l}(1.009) \\
-1.646\end{array}$ & $\begin{array}{l}(0.847) \\
-3.117\end{array}$ & $\begin{array}{c}(1.159) \\
1.638\end{array}$ & $\begin{array}{l}(0.748) \\
-2.133^{\star \star}\end{array}$ & $\begin{array}{l}(0.573) \\
-0.312\end{array}$ & $\begin{array}{c}(1.297) \\
0.669\end{array}$ \\
\hline Interaction & $(2.102)$ & (1.186) & $(1.293)$ & (1.163) & $(0.929)$ & $(1.186)$ & $(1.831)$ & $(1.859)$ & $(1.503)$ & $(0.885)$ & $(1.214)$ & $(1.222)$ \\
\hline Physical work & $\begin{array}{c}-1.671^{* *} \\
(0.579)\end{array}$ & $\begin{array}{c}-2.612^{* \star *} \\
(0.816)\end{array}$ & $\begin{array}{c}-1.835^{\star \star \star} \\
(0.497)\end{array}$ & $\begin{array}{c}-2.515^{\star \star \star} \\
(0.402)\end{array}$ & $\begin{array}{c}-1.259^{\star \star \star} \\
(0.351)\end{array}$ & $\begin{array}{l}-1.465 \\
(0.919)\end{array}$ & $\begin{array}{c}-2.405^{\star \star \star} \\
(0.669)\end{array}$ & $\begin{array}{l}-0.840^{*} \\
(0.458)\end{array}$ & $\begin{array}{l}-0.938^{*} \\
(0.537)\end{array}$ & $\begin{array}{c}-1.531^{\star \star *} \\
(0.326)\end{array}$ & $\begin{array}{c}0.003 \\
(0.627)\end{array}$ & $\begin{array}{c}0.462 \\
(1.134)\end{array}$ \\
\hline Constant & $\begin{array}{c}275.210^{* * *} \\
(13.583)\end{array}$ & $\begin{array}{c}262.219^{\star \star \star} \\
(12.839)\end{array}$ & $\begin{array}{c}284.975^{\star \star \star} \\
(15.745)\end{array}$ & $\begin{array}{c}227.096^{\star * \star} \\
(14.450)\end{array}$ & $\begin{array}{c}238.690^{\star \star \star} \\
(13.413)\end{array}$ & $\begin{array}{c}243.589^{\star \star \star} \\
(10.802)\end{array}$ & $\begin{array}{c}280.984^{\star * *} \\
(10.629)\end{array}$ & $\begin{array}{c}250.840^{\star \star *} \\
(7.600)\end{array}$ & $\begin{array}{c}256.110^{* \star *} \\
(13.078)\end{array}$ & $\begin{array}{c}270.692^{\star \star *} \\
(7.172)\end{array}$ & $\begin{array}{c}243.138^{\star \star *} \\
(6.100)\end{array}$ & $\begin{array}{c}222.627^{\star * \star} \\
(8.041)\end{array}$ \\
\hline $\begin{array}{l}\text { Observations } \\
\text { R-squared }\end{array}$ & $\begin{array}{l}1,011 \\
0.265\end{array}$ & $\begin{array}{l}1,183 \\
0.240\end{array}$ & $\begin{array}{l}1,328 \\
0.281\end{array}$ & $\begin{array}{l}1,534 \\
0.231\end{array}$ & $\begin{array}{l}3,311 \\
0.222\end{array}$ & $\begin{array}{l}1,401 \\
0.279\end{array}$ & $\begin{array}{l}1,123 \\
0.238\end{array}$ & $\begin{array}{l}1,431 \\
0.330\end{array}$ & $\begin{array}{l}1,059 \\
0.282\end{array}$ & $\begin{array}{l}2,831 \\
0.243\end{array}$ & $\begin{array}{l}1,180 \\
0.372\end{array}$ & $\begin{array}{c}750 \\
0.284\end{array}$ \\
\hline \multirow{2}{*}{ R-squared } & (13) & $(14)$ & (15) & $(16)$ & (17) & $(18)$ & (19) & $(20)$ & $(21)$ & (22) & (23) & \\
\hline & $\begin{array}{c}\text { Numerical and } \\
\text { material } \\
\text { recording } \\
\text { clerks }\end{array}$ & $\begin{array}{l}\text { Other } \\
\text { clerical } \\
\text { support } \\
\text { workers }\end{array}$ & $\begin{array}{l}\text { Personal } \\
\text { service } \\
\text { workers }\end{array}$ & $\begin{array}{c}\text { Sales } \\
\text { workers }\end{array}$ & $\begin{array}{c}\text { Personal } \\
\text { care workers }\end{array}$ & $\begin{array}{l}\text { Building and } \\
\text { related trades } \\
\text { workers }\end{array}$ & $\begin{array}{c}\text { Metal, } \\
\text { machinery } \\
\text { and related } \\
\text { trades } \\
\text { workers } \\
\end{array}$ & $\begin{array}{c}\text { Stationary } \\
\text { plant and } \\
\text { machine } \\
\text { operators }\end{array}$ & $\begin{array}{c}\text { Drivers and } \\
\text { mobile plant } \\
\text { operators }\end{array}$ & $\begin{array}{c}\text { Cleaners } \\
\text { and helpers }\end{array}$ & $\begin{array}{l}\text { Labourers in } \\
\text { mining, } \\
\text { construction, } \\
\text { manufacturing }\end{array}$ & \\
\hline \multirow[t]{2}{*}{ Abstract reasoning } & $2.227^{\star \star \star}$ & $2.404^{*}$ & $1.978^{* *}$ & $2.726^{\star \star \star}$ & $2.427^{\star \star \star}$ & $2.165^{\star \star \star}$ & $2.061^{* *}$ & $3.390^{\star \star \star}$ & $3.896^{\star \star \star}$ & 1.908 & $4.766^{\star \star \star}$ & \\
\hline & $(0.609)$ & $(1.332)$ & $(0.707)$ & $(0.867)$ & $(0.626)$ & $(0.508)$ & $(0.749)$ & $(0.891)$ & $(0.994)$ & $(1.208)$ & $(1.032)$ & \\
\hline \multirow[t]{2}{*}{ Job latitude } & $3.028^{\star \star *}$ & $2.953^{\star \star}$ & 1.505 & -0.540 & -0.500 & $2.111^{* *}$ & 0.356 & $3.676^{* *}$ & 0.733 & $3.247^{\star \star \star}$ & 2.849 & \\
\hline & $(0.844)$ & (1.197) & (1.104) & $(0.711)$ & $(0.642)$ & $(0.802)$ & (1.393) & $(1.429)$ & $(1.117)$ & $(1.034)$ & (1.641) & \\
\hline \multirow[t]{2}{*}{ Interaction } & -1.885 & -0.087 & 1.711 & 0.662 & 1.270 & 0.738 & 0.208 & -0.696 & -1.445 & 1.700 & 1.168 & \\
\hline & (1.185) & (1.066) & (1.187) & $(0.815)$ & $(0.779)$ & (1.459) & (1.891) & (1.321) & (1.633) & (1.599) & (2.493) & \\
\hline \multirow[t]{2}{*}{ Physical work } & $-1.784^{\star \star \star}$ & -0.585 & $-1.062^{*}$ & $-0.787^{\star \star \star}$ & -0.422 & 0.306 & -0.963 & 0.247 & $-1.613^{\star *}$ & -0.075 & -0.609 & \\
\hline & $(0.473)$ & $(0.338)$ & $(0.581)$ & $(0.267)$ & $(0.349)$ & (1.498) & $(0.827)$ & $(0.987)$ & $(0.713)$ & $(1.005)$ & (1.101) & \\
\hline \multirow[t]{2}{*}{ Constant } & $251.137^{\star \star \star}$ & $225.143^{\star \star \star}$ & $238.778^{\star \star \star}$ & $243.706^{\star \star \star}$ & $238.860^{\star \star \star}$ & $210.526^{\star \star \star}$ & $233.944^{\star * *}$ & $228.280^{\star * *}$ & $242.873^{\star \star \star}$ & $199.748^{* \star \star}$ & $208.134^{\star * \star}$ & \\
\hline & $(7.971)$ & $(11.278)$ & $(6.557)$ & $(5.641)$ & $(7.091)$ & $(15.904)$ & $(11.992)$ & $(10.519)$ & $(6.718)$ & $(10.548)$ & $(12.891)$ & \\
\hline Observations & 1,404 & 755 & 1,510 & 2,719 & 2,090 & 1,130 & 1,094 & 924 & 1,206 & 1,047 & 876 & \\
\hline R-squared & 0.288 & 0.295 & 0.315 & 0.279 & 0.271 & 0.243 & 0.229 & 0.346 & 0.216 & 0.221 & 0.235 & \\
\hline
\end{tabular}

(1) full set of explanatory variables as shown in Table 3 .

Source: OECD Survey of Adult Skills (PIAAC) 